\title{
Review
}

Qingfeng Guo* and Yuming Hua

\section{The assessment of circulating cell-free DNA as a diagnostic tool for breast cancer: an updated systematic review and meta-analysis of quantitative and qualitative ssays}

https://doi.org/10.1515/cclm-2021-0193

Received February 10, 2021; accepted April 23, 2021;

published online May 6, 2021

\begin{abstract}
Objectives: This updated meta-analysis aimed to assess the diagnostic accuracy of circulating cell-free DNA (cfDNA) in breast cancer (BC).

Content: An extensive systematic search was performed in PubMed, Scopus, Embase, and Science Direct databases to retrieve all related literature. Various diagnostic estimates, including sensitivity (SE), specificity (SP), likelihood ratios (LRs), diagnostic odds ratio (DOR), and area under the curve (AUC) of summary receiver operating characteristic (sROC) curve, were also calculated using bivariate linear mixed models.
\end{abstract}

Summary: In this meta-analysis, 57 unique articles (130 assays) on $4246 \mathrm{BC}$ patients and 2,952 controls, were enrolled. For quantitative approaches, pooled SE, SP, PLR, NLR, DOR, and AUC were obtained as 0.80, 0.88, 6.7, 0.23, 29 , and 0.91, respectively. Moreover, for qualitative approaches, pooled SE and SP for diagnostic performance were obtained as 0.36 and 0.98 , respectively. In addition, PLR was 14.9 and NLR was 0.66. As well, the combined DOR was 23, and the AUC was 0.79 .

Outlook: Regardless of promising SE and SP, analysis of LRs suggested that quantitative assays are not robust enough neither for BC confirmation nor for its exclusion. On the other hand, qualitative assays showed satisfying performance only for confirming the diagnosis of $\mathrm{BC}$, but not for

*Corresponding author: Qingfeng Guo, Department of General Surgery, Affiliated Hospital of Jiangnan University (Original Area of Wuxi No. 3 People's Hospital), Wuxi, 210000, P.R. China,

E-mail: guoqf_jdfy@126.com

Yuming Hua, Department of General Surgery, Affiliated Hospital of Jiangnan University (Original Area of Wuxi No. 3 People's Hospital), Wuxi, P.R. China its exclusion. Furthermore, qualitative cfDNA assays showed a better diagnostic performance in patients at the advanced stage of cancer, which represented no remarkable clinical significance as a biomarker for early detection.

Keywords: breast cancer; cell-free DNA; cfDNA; circulating DNA; diagnostic accuracy; diagnostic marker.

\section{Introduction}

Breast cancer (BC) is known as the most common cancer with the highest mortality rate among women [1]. Early detection methods have helped in reducing BC mortality [2]. Currently, it was indicated that mammography as a gold standard method used for early detection of $\mathrm{BC}$ can reduce mortality up to $30 \%$ [3]. However, $13 \%$ of BC patients are missed by mammography due to some factors such as overlapping with dense fibroglandular tissue, tumor size, and patient's age $[4,5]$. Additionally, false-positive detection in mammograms may cause over-treatment as well as radiation-induced disease $[6,7]$. The current serum-based biomarkers such as cancer antigen 15-3 (CA15-3) and carcinoembryonic antigen (CEA) also did not show satisfactory result regarding highly accurate diagnosis of $\mathrm{BC}[8,9]$. Therefore, it is necessary to develop novel minimally-invasive biomarkers, in order to achieve a sufficient diagnostic performance for early detection of $\mathrm{BC}$ in the clinical practice.

Circulating cell-free DNA (cfDNA) can be found in both healthy individuals and cancer patients; however, its level in cancer patients has been reported to be significantly higher compared to normal people [10]. The release of cfDNA into the bloodstream from cancer cells is called circulating tumor DNA (ctDNA). Correspondingly, the amount of cf DNA is determined by the level of necrosis and apoptosis [11-13]. Different valuable information on tumor drug resistance, clonal heterogeneity, and disease progression can be achieved by analyzing cfDNA via the evaluation of cfDNA for aberrant level, gene 
mutations, microsatellite alteration, loss of heterozygosity, single nucleotide polymorphism, and aberrant methylation $[14,15]$. Different sensitive techniques such as sequencingbased methods [16-18] and digital PCR-based approaches [19-21] can also be applied to evaluate cfDNA in various cancer types, including hepatocellular carcinoma, lung, pancreatic carcinoma, colorectal, prostate, ovarian, and breast $[16,17,19,22]$. Being repetitive, noninvasive, and easy to perform the analysis, are known as the major benefits of cfDNA as a diagnostic tool. Moreover, it is notable that CfDNA holds a great promise as a supplement or alternative for conventional biomarkers and tissue biopsy in early diagnosis of tumor, assessing tumor's burden, and treatment monitoring.

Several studies have previously assessed the diagnostic accuracy of circulating cfDNA in terms of quantitative and qualitative changes among $\mathrm{BC}$ patients. By the term of Quantitative changes, it is referred to aberrant levels of cfDNA and circulating nucleosomes, while qualitative changes include epigenetic modifications, loss of heterozygosity ( $\mathrm{LOH}$ ), and single gene mutation. However, inconsistent results regarding its clinical use still exist in the previously performed works. Hence, this updated systematic review and meta-analysis aimed to integrate data from previous studies, in order to evaluate the diagnostic performance of cfDNA in BC diagnosis.

\section{Methods}

\section{Literature search strategy}

In this study, we performed an extensive search to find relevant articles in PubMed, Science Direct, Web of Science, and Scopus up databases to August 31, 2020, without applying any limit. A combination of keywords has been generated by arranging the medical subject heading $(\mathrm{MeSH})$ terms and free words concerning search tips in each database as follows: ("circulating” OR "plasma” OR "serum” OR "cellfree”) AND ("DNA” OR “cfDNA” OR “ctDNA") AND ("breast cancer” OR "breast neoplasm") AND ("diagnostic accuracy" OR "diagnostic"). Furthermore, the reference lists of the obtained relevant literatures have been evaluated to find additional studies. Ineligible studies have been excluded by reading their titles and abstracts, then the full texts of each one of the remained study have been retrieved and comprehensively evaluated. This study has been performed in accordance with the Preferred Reporting Items for Systematic Reviews and MetaAnalyses (PRISMA) Statement [23].

\section{Inclusion and exclusion criteria}

The inclusion criteria were as follows: (a) all the patients recruited in the study must be diagnosed with BC using a gold standard test; (b) a case control design evaluating the diagnostic accuracy of cfDNA in plasma or serum for BC; and (c) availability of raw data on diagnostic accuracy measures including true positives (TP), true negatives (TN), false positives (FP), and false negatives (FN) or some estimates such as sensitivity (SE) and specificity (SP).

The main exclusion criteria were the followings: (a) duplicate studies; (b) meta-analyses, reviews, book chapters, conference abstracts, and letters to the editors; (c) unavailability of sufficient data; and (d) unavailability of full texts.

\section{Data extraction and quality assessment}

At this stage, we extracted the following data from the enrolled articles: authors' name, year of publication, country of origin, design of the study, type of controls, type of samples, experimental methods, assay type, cutoff values, and number of the participants. Additionally, the numerical values for TP, FP, FN, and TN have been directly achieved or extracted from given SE and SP. The quality of the enrolled studies have been assessed in terms of the revised quality assessment of diagnostic accuracy studies-2 (QUADAS-2) criteria [24]. Finally, discrepancies have been resolved by consensus.

\section{Biostatistical methods}

Several diagnostic estimations were used to present the results of this meta-synthesis, including SE, SP, likelihood ratios (LRs), and diagnostic odds ratio (DOR). In addition, area under the curve of summary receiver operating characteristic curves (sROC-AUC) was used as a global measurement for testing the accuracy. Subgroup analysis and meta-regression were also performed to evaluate the effect of different covariates and potential sources of heterogeneity on the diagnostic measures [25]. Moreover, Fagan's nomogram and likelihood ratio scattergram were used to present the clinical utility [26]. Publication bias was assessed using Deek's funnel plot asymmetry test [27]. Accordingly, trim and fill analysis were applied in case of any publication bias to judge the effect of bias on the pooled estimates [28]. The threshold effect was assessed by Spearman's correlation coefficient test, and $I^{2}$ and $\chi^{2}$ were used to evaluate the heterogeneity among the enrolled articles [29,30]. Of note, all these test measures were calculated by bivariate mixed effects regression using Stata 14.2 which incorporates any possible correlation between SE and SP using a random effect model (version 14.2; Stata Corporation, College Station, TX) and Meta-DiSc (version 1.4, Ramon y Cajal Hospital, Madrid, Spain).

\section{Results}

\section{Selection of studies}

The procedures of literature recapturing and inclusion are presented in Figure 1. In this regard, we found 1,396 relevant articles from different databases. After excluding 282 duplicated articles, 955 articles were also excluded through the evaluation of their titles and abstracts due to having unrelated study design or unavailability of their data. 
Moreover, of the remaining 159 papers, 102 have been excluded due to details presented in Figure 1. Subsequently, this meta-analysis has been performed on 57 articles at last (130 assays).

\section{Baseline characteristics and quality assessment}

Table 1 represents the characteristics of 57 included articles (130 assays) [21, 31-86]. Accordingly, a total of 7,198 individuals, including $4246 \mathrm{BC}$ patients and 2,952 controls, were enrolled in this diagnostic analysis. Healthy volunteers were selected as the single control group in 98 assays and patients with benign breast lesions were assigned as the only control group in nine assays. In addition, in 23 assays, a mix of healthy volunteers and patients with benign breast lesions was chosen as the control group. In terms of regions, 57 assays were conducted in Asia (44\%), 11 in Africa (9\%), 46 in Europe (35\%), and 16 in America (12\%). Of note, out of the selected articles, four articles had a prospective design, 28 articles had a retrospective design, and 25 articles had no clear design. One hundred and one assays evaluated cfDNA as qualitative indicators including loss of heterozygosity $(\mathrm{LOH})(\mathrm{n}=3)$, allelic imbalance (AI) $(n=1)$, single gene mutation (Mut) $(n=4)$, microsatellite instability $(\mathrm{MI})(\mathrm{n}=1)$, repetitive elements $(\mathrm{n}=1)$ and aberrant methylation (M) $(n=91)$. Meanwhile, 29 assays evaluated cfDNA integrity (DI) index ( $\mathrm{n}=7)$ and aberrant concentrations of cfDNA as a quantitative indicator $(\mathrm{n}=22)$. In 60 assays the sample size was $\geq 100$ cases while in the remaining assays the sample size was $<100$ cases. The sample types were categorized as plasma ( $\mathrm{n}=50$ assays) and serum ( $\mathrm{n}=80$ assays).

The result of the quality assessment in terms of QUADAS-2 criteria is presented in Figure 2. Accordingly, the majority of the enrolled studies fulfilled these criteria.

\section{Diagnostic accuracy}

The pooled SE, SP, PLR, NLR, and DOR are considered as indicators employed to measure the diagnostic performance. For quantitative approaches, the pooled SE, SP, PLR, NLR, DOR, and AUC were obtained as 0.80 (95\% CI: 0.71-0.86, $I^{2}$ : 92.49\%) (Figure 3A), 0.88 (95\% CI: 0.82-0.92, $I^{2}: 85.26 \%$ )

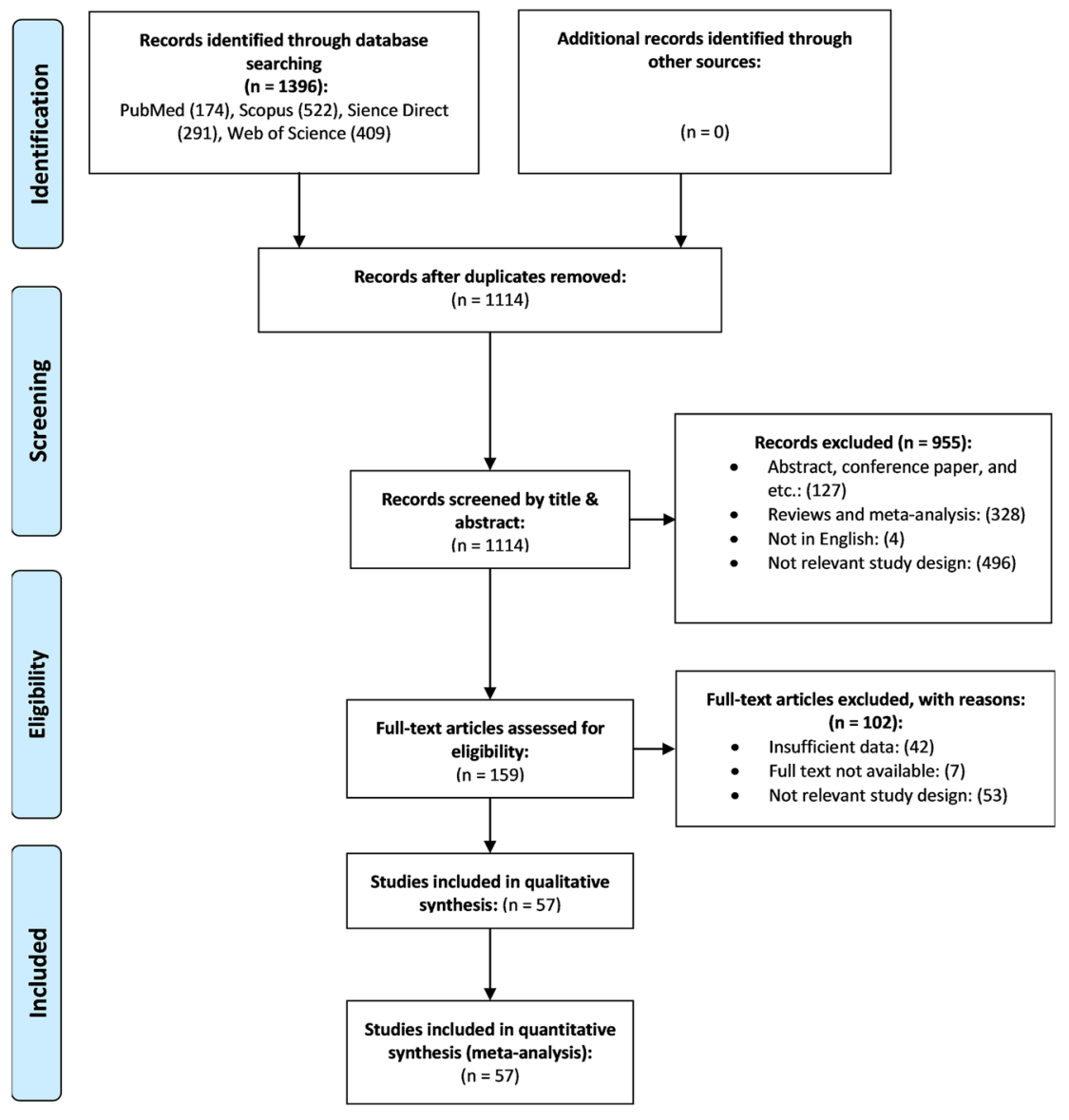

Figure 1: PRISMA flowchart of the identification of eligible studies. 
Table 1: Characteristics of the included studies.

\begin{tabular}{|c|c|c|c|c|c|c|c|c|c|}
\hline $\begin{array}{l}\text { Study ID } \\
\text { Author, year }\end{array}$ & Country & Sample & Design & Controls & Method & Assay type & Cutoff & $\begin{array}{l}\text { No. } \\
\text { P/C }\end{array}$ & $\begin{array}{l}\text { TP/FP/ } \\
\text { FN/TN }\end{array}$ \\
\hline Agassi et al. (2015) & Isreal & Serum & Retrospective & Healthy & Fluorescent assay & Q & $600 \mathrm{ng} / \mathrm{mL}$ & $\begin{array}{r}36 / \\
16\end{array}$ & $\begin{array}{l}26 / 4 / \\
10 / 12\end{array}$ \\
\hline \multirow[t]{7}{*}{$\begin{array}{l}\text { Agostini et al. } \\
(2012)\end{array}$} & Italy & Plasma & Retrospective & Healthy & RT-PCR & Q (ALU 247) & $2 \mathrm{ng} / \mathrm{mL}$ & $\begin{array}{r}39 / \\
49\end{array}$ & $\begin{array}{r}39 / 0 / \\
0 / 49\end{array}$ \\
\hline & & & & & RT-PCR & Q (ALU 115) & $9.3 \mathrm{ng} / \mathrm{mL}$ & $\begin{array}{r}39 / \\
49\end{array}$ & $\begin{array}{r}37 / 0 / \\
2 / 49\end{array}$ \\
\hline & & & & & RT-PCR & $\mathrm{DI}$ & 0.6 & $\begin{array}{r}49 / \\
49\end{array}$ & $\begin{array}{l}36 / \\
11 /\end{array}$ \\
\hline & & & & & & & & & $13 / 38$ \\
\hline & & & & & MSP & M (RASSF1A) & NA & $\begin{array}{r}39 / \\
49\end{array}$ & $\begin{array}{r}9 / 0 / \\
30 / 49\end{array}$ \\
\hline & & & & & MSP & M (MAL) & NA & $\begin{array}{r}39 / \\
49\end{array}$ & $\begin{array}{r}5 / 0 / \\
34 / 49\end{array}$ \\
\hline & & & & & MSP & M (SFPR1) & NA & $\begin{array}{r}39 / \\
49\end{array}$ & $\begin{array}{l}16 / 0 / \\
23 / 49\end{array}$ \\
\hline Beaver et al. (2014) & USA & Plasma & Retrospective & Healthy & $\mathrm{ddPCR}$ & Mut (PI3CA) & NA & $\begin{array}{r}15 / \\
14\end{array}$ & $\begin{array}{r}14 / 0 / \\
1 / 14\end{array}$ \\
\hline Beck et al. (2010) & USA & Serum & Retrospective & Healthy & NGS & $\begin{array}{l}\text { Repetitive } \\
\text { elements }\end{array}$ & NA & $\begin{array}{r}10 / \\
87\end{array}$ & $\begin{array}{r}9 / 4 / 1 / \\
83\end{array}$ \\
\hline \multirow[t]{2}{*}{ Board et al. (2010) } & UK & Serum & Retrospective & Healthy & ARMS-PCR & Mut (PI3CA) & NA & $\begin{array}{r}14 / \\
16\end{array}$ & $\begin{array}{r}0 / 0 / \\
14 / 16\end{array}$ \\
\hline & & & & & ARMS-PCR & Mut (PI3CA) & NA & $\begin{array}{r}10 / \\
31\end{array}$ & $\begin{array}{r}8 / 1 / 2 / \\
30\end{array}$ \\
\hline $\begin{array}{l}\text { Catarino et al. } \\
(2008)\end{array}$ & Portugal & Plasma & Retrospective & Healthy & RT-PCR & Q & $106 \mathrm{ng} / \mathrm{mL}$ & $\begin{array}{r}175 / \\
80\end{array}$ & $\begin{array}{l}76 / 7 / \\
99 / 73\end{array}$ \\
\hline Chen et al. (1999) & Switzerland & Serum & NA & Healthy & QPCR & $\mathrm{LOH}$ & $30 \%$ & $\begin{array}{r}21 / \\
10\end{array}$ & $\begin{array}{l}10 / 0 / \\
11 / 10\end{array}$ \\
\hline $\begin{array}{l}\text { Chimonidou et al. } \\
\text { (2013a) }\end{array}$ & Greece & Plasma & NA & Healthy & RT-MSP & $M($ Sox17) & NA & $\begin{array}{r}138 / \\
49\end{array}$ & $\begin{array}{l}43 / 1 / \\
95 / 48\end{array}$ \\
\hline $\begin{array}{l}\text { Chimonidou et al. } \\
\text { (2013b) }\end{array}$ & Greece & Plasma & Retrospective & Healthy & MSP & M (CST6) & NA & $\begin{array}{r}123 / \\
37\end{array}$ & $\begin{array}{l}49 / 0 / \\
74 / 37\end{array}$ \\
\hline Divella et al. (2009) & Italy & Plasma & NA & Mixed & RT-PCR & Q & NA & $\begin{array}{r}122 / \\
80\end{array}$ & $\begin{array}{l}61 / 8 / \\
61 / 72\end{array}$ \\
\hline \multirow[t]{3}{*}{$\begin{array}{l}\text { Dulaimi et al. } \\
(2004)\end{array}$} & USA & Serum & NA & Healthy & MSP & $M(A P C)$ & NA & $\begin{array}{r}34 / \\
20\end{array}$ & $\begin{array}{l}10 / 0 / \\
24 / 20\end{array}$ \\
\hline & & & & & MSP & M (RASSF1A) & NA & $\begin{array}{r}34 / \\
20\end{array}$ & $\begin{array}{l}19 / 0 / \\
15 / 20\end{array}$ \\
\hline & & & & & MSP & M (DAPK) & NA & $\begin{array}{r}34 / \\
20\end{array}$ & $\begin{array}{l}12 / 0 / \\
22 / 20\end{array}$ \\
\hline \multirow[t]{2}{*}{ Ebeid et al. (2016) } & Egypt & Serum & NA & Healthy & MSP & M (RASSF1A) & NA & $\begin{array}{r}80 / \\
80\end{array}$ & $\begin{array}{l}50 / 0 / \\
30 / 80\end{array}$ \\
\hline & Egypt & Serum & NA & Healthy & MSP & $\mathrm{M}(\mathrm{PCDH} 10)$ & NA & $\begin{array}{r}80 / \\
80\end{array}$ & $\begin{array}{l}34 / 0 / \\
46 / 80\end{array}$ \\
\hline Fu et al. (2015) & China & Plasma & Retrospective & Healthy & MSP & M (Sox17) & NA & $\begin{array}{r}155 / \\
60\end{array}$ & $\begin{array}{l}90 / 0 / \\
65 / 60\end{array}$ \\
\hline Gal et al. (2004) & UK & Serum & Retrospective & Healthy & PCR & Q & NA & $\begin{array}{r}96 / \\
24\end{array}$ & $\begin{array}{l}68 / 2 / \\
28 / 22\end{array}$ \\
\hline Geng et al. (2013) & China & Plasma & Retrospective & Healthy & RT-PCR & Q & $\begin{array}{l}2.49106 \\
\text { copies/mL) }\end{array}$ & $\begin{array}{r}229 / \\
43\end{array}$ & $\begin{array}{r}181 / \\
10 / \\
48 / 33\end{array}$ \\
\hline Gong et al. (2012) & China & Serum & Retrospective & Mixed & PCR & Q & $471 \mathrm{ng} / \mathrm{mL}$ & $\begin{array}{r}200 / \\
200\end{array}$ & $\begin{array}{r}178 / \\
10 / \\
22 / \\
190\end{array}$ \\
\hline
\end{tabular}


Table 1: (continued)

\begin{tabular}{|c|c|c|c|c|c|c|c|c|c|}
\hline $\begin{array}{l}\text { Study ID } \\
\text { Author, year }\end{array}$ & Country & Sample & Design & Controls & Method & Assay type & Cutoff & $\begin{array}{l}\text { No. } \\
\text { P/C }\end{array}$ & $\begin{array}{l}\text { TP/FP/ } \\
\text { FN/TN }\end{array}$ \\
\hline $\begin{array}{l}\text { Hashad et al. } \\
\text { (2012) }\end{array}$ & Egypt & Serum & NA & Healthy & RT-PCR & $\mathrm{Q}$ & 34 & $\begin{array}{r}42 / \\
27\end{array}$ & $\begin{array}{r}41 / 1 / \\
1 / 26\end{array}$ \\
\hline \multirow[t]{4}{*}{ Hoque et al. (2006) } & Senegal & Plasma & Retrospective & Healthy & MSP & M (GSTP1) & 0 & $\begin{array}{r}47 / \\
38\end{array}$ & $\begin{array}{l}12 / 0 / \\
35 / 38\end{array}$ \\
\hline & & & Retrospective & Healthy & MSP & $M(\operatorname{RAR} \beta 2)$ & $2.6 \times 10^{-8}$ & $\begin{array}{r}47 / \\
38\end{array}$ & $\begin{array}{l}12 / 3 / \\
35 / 35\end{array}$ \\
\hline & & & Retrospective & Healthy & MSP & M (RASSF1A) & $6.5 \times 10^{-3}$ & $\begin{array}{r}47 / \\
38\end{array}$ & $\begin{array}{l}15 / 2 / \\
32 / 36\end{array}$ \\
\hline & & & Retrospective & Healthy & MSP & $M(A P C)$ & 3.2 & $\begin{array}{r}47 / \\
38\end{array}$ & $\begin{array}{r}8 / 0 / \\
39 / 38\end{array}$ \\
\hline \multirow[t]{2}{*}{ Huang et al. (2006) } & China & Plasma & Retrospective & Healthy & RT-PCR & Q & $19 \mathrm{ng} / \mathrm{mL}$ & $\begin{array}{r}61 / \\
27\end{array}$ & $\begin{array}{r}58 / 3 / \\
3 / 24\end{array}$ \\
\hline & & & & NBC & RT-PCR & Q & $22 \mathrm{ng} / \mathrm{mL}$ & $\begin{array}{r}61 / \\
33\end{array}$ & $\begin{array}{r}57 / \\
11 / 4 /\end{array}$ \\
\hline \multirow[t]{2}{*}{$\begin{array}{l}\text { Hussein et al. } \\
\text { (2019) }\end{array}$} & Egypt & Plasma & Retrospective & Healthy & RT-PCR & Q (ALU 115) & $>9.6$ & $\begin{array}{r}40 / \\
10\end{array}$ & $\begin{array}{l}27 / 0 / \\
13 / 10\end{array}$ \\
\hline & & & & Healthy & RT-PCR & $\begin{array}{l}\text { DI (ALU 247/ } \\
\text { ALU 115) }\end{array}$ & $>6.35$ & $\begin{array}{r}40 / \\
10\end{array}$ & $\begin{array}{l}28 / 0 / \\
12 / 10\end{array}$ \\
\hline \multirow[t]{3}{*}{ Jing et al. (2007) } & China & Serum & NA & Healthy & MSP & M (BRCA1) & NA & $\begin{array}{r}38 / \\
20\end{array}$ & $\begin{array}{l}14 / 0 / \\
24 / 20\end{array}$ \\
\hline & & & & & MSP & $M(p 16)$ & NA & $\begin{array}{r}38 / \\
20\end{array}$ & $\begin{array}{l}13 / 0 / \\
25 / 20\end{array}$ \\
\hline & & & & & MSP & $M(14-3-3 \varrho)$ & NA & $\begin{array}{r}38 / \\
20\end{array}$ & $\begin{array}{r}33 / 0 / \\
5 / 20\end{array}$ \\
\hline \multirow[t]{3}{*}{ Jing et al. (2008) } & China & Serum & NA & Healthy & MSP & M (BRCA1) & NA & $\begin{array}{r}102 / \\
20\end{array}$ & $\begin{array}{l}33 / 0 / \\
69 / 20\end{array}$ \\
\hline & China & Serum & NA & Healthy & MSP & $M(p 16)$ & NA & $\begin{array}{r}102 / \\
20\end{array}$ & $\begin{array}{l}30 / 0 / \\
72 / 20\end{array}$ \\
\hline & China & Serum & NA & Healthy & MSP & $M(14-3-3 \varrho)$ & NA & $\begin{array}{r}102 / \\
20\end{array}$ & $\begin{array}{l}84 / 0 / \\
18 / 20\end{array}$ \\
\hline \multirow[t]{10}{*}{ Jing et al. (2010) } & China & Serum & NA & Mixed & MSP & M (RASSF1A) & NA & $\begin{array}{r}50 / \\
50\end{array}$ & $\begin{array}{l}37 / 3 / \\
13 / 47\end{array}$ \\
\hline & & & & & MSP & $\mathrm{M}(\mathrm{CDH} 1)$ & NA & $\begin{array}{r}50 / \\
50\end{array}$ & $\begin{array}{l}30 / 5 / \\
20 / 45\end{array}$ \\
\hline & & & & & MSP & $M($ RAR $\beta 2)$ & NA & $\begin{array}{r}50 / \\
50\end{array}$ & $\begin{array}{l}21 / 2 / \\
29 / 48\end{array}$ \\
\hline & & & & & MSP & M (BRCA1) & NA & $\begin{array}{r}50 / \\
50\end{array}$ & $\begin{array}{l}17 / 0 / \\
33 / 50\end{array}$ \\
\hline & & & & & MSP & $M(\mathrm{p} 16)$ & NA & $\begin{array}{r}50 / \\
50\end{array}$ & $\begin{array}{l}15 / 0 / \\
35 / 50\end{array}$ \\
\hline & & & & & MSP & $M(E r \alpha)$ & NA & $\begin{array}{r}50 / \\
50\end{array}$ & $\begin{array}{l}23 / 5 / \\
27 / 45\end{array}$ \\
\hline & & & & & MSP & $M(\operatorname{cox} 2)$ & NA & $\begin{array}{r}50 / \\
50\end{array}$ & $\begin{array}{r}6 / 1 / \\
44 / 49\end{array}$ \\
\hline & & & & & MSP & $M(A P C)$ & NA & $\begin{array}{r}50 / \\
50\end{array}$ & $\begin{array}{l}14 / 0 / \\
36 / 50\end{array}$ \\
\hline & & & & & MSP & M (DAPK) & NA & $\begin{array}{r}50 / \\
50\end{array}$ & $\begin{array}{r}9 / 0 / \\
41 / 50\end{array}$ \\
\hline & & & & & MSP & M (FHIT) & NA & $\begin{array}{r}50 / \\
50\end{array}$ & $\begin{array}{r}5 / 0 / \\
45 / 50\end{array}$ \\
\hline Kim et al. (2010) & Korea & Serum & Retrospective & Healthy & QM-MSP & $M(\mathrm{HIN}-1)$ & $0.03 \%$ & $\begin{array}{r}119 / \\
125\end{array}$ & $\begin{array}{r}37 / 0 / \\
82 /\end{array}$ \\
\hline
\end{tabular}


Table 1: (continued)

\begin{tabular}{|c|c|c|c|c|c|c|c|c|c|}
\hline $\begin{array}{l}\text { Study ID } \\
\text { Author, year }\end{array}$ & Country & Sample & Design & Controls & Method & Assay type & Cutoff & $\begin{array}{l}\text { No. } \\
\text { P/C }\end{array}$ & $\begin{array}{l}\text { TP/FP/ } \\
\text { FN/TN }\end{array}$ \\
\hline & & & & & QM-MSP & $M($ RASSF1A) & $0.08 \%$ & $\begin{array}{r}119 / \\
125\end{array}$ & $\begin{array}{r}39 / 6 / \\
80 / \\
119\end{array}$ \\
\hline & & & & & QM-MSP & M (RAR-B) & $1.04 \%$ & $\begin{array}{r}119 / \\
125\end{array}$ & $\begin{array}{r}103 / \\
8 / 16 / \\
117\end{array}$ \\
\hline & & & & & QM-MSP & $M$ (Twist) & $0.86 \%$ & $\begin{array}{r}119 / \\
125\end{array}$ & $\begin{array}{l}65 / \\
10 / \\
54 / \\
115\end{array}$ \\
\hline $\begin{array}{l}\text { Kirkizlar et al. } \\
\text { (2015) }\end{array}$ & USA & Serum & NA & Healthy & NGS & $\mathrm{Al}$ & $0.45 \%$ & $\begin{array}{r}11 / \\
30\end{array}$ & $\begin{array}{r}8 / 0 / 3 / \\
30\end{array}$ \\
\hline \multirow[t]{2}{*}{$\begin{array}{l}\text { Zachariah et al. } \\
\text { (2008) }\end{array}$} & Switzerland & Plasma & Retrospective & Healthy & Multiplex RT-PCR & $\mathrm{Q}$ (nDNA) & $1866 \mathrm{GE} / \mathrm{mL}$ & $\begin{array}{r}52 / \\
70\end{array}$ & $\begin{array}{r}42 / \\
22 / \\
10 / 48\end{array}$ \\
\hline & & & & & Multiplex RT-PCR & $Q(m t D N A)$ & $\begin{array}{l}\text { 463,282 GE/ } \\
\mathrm{mL}\end{array}$ & $\begin{array}{r}52 / \\
70\end{array}$ & $\begin{array}{l}28 / 9 / \\
24 / 61\end{array}$ \\
\hline Leon et al. (1977) & USA & Serum & Retrospective & Healthy & Radioimmunoassay & Q & $50 \mathrm{ng} / \mathrm{mL}$ & $\begin{array}{r}32 / \\
55\end{array}$ & $\begin{array}{l}12 / 4 / \\
20 / 51\end{array}$ \\
\hline \multirow[t]{2}{*}{ Li et al. (2016) } & China & Plasma & NA & Healthy & BS-seq & $M(E G F R)$ & NA & $\begin{array}{r}86 / \\
67\end{array}$ & $\begin{array}{r}70 / \\
41 / \\
16 / 26\end{array}$ \\
\hline & & & & & BS-seq & $M(P P M 1 A)$ & NA & $\begin{array}{r}86 / \\
67\end{array}$ & $\begin{array}{r}65 / \\
37 / \\
21 / 30\end{array}$ \\
\hline Li et al. (2018) & China & Plasma & Retrospective & Mixed & BS-seq & M (NBPF1) & NA & $\begin{array}{r}52 / \\
61\end{array}$ & $\begin{array}{l}35 / \\
27 /\end{array}$ \\
\hline \multirow[t]{2}{*}{$\begin{array}{l}\text { Mahmoud et al. } \\
\text { (2015) }\end{array}$} & Egypt & Plasma & Retrospective & NBC & RT-PCR & $\mathrm{Q}$ (nDNA) & $\begin{array}{l}2,236 \text { copy/ } \\
\mu \mathrm{L}\end{array}$ & $\begin{array}{r}50 / \\
30\end{array}$ & $\begin{array}{l}17 / 34 \\
38 / 9 / \\
12 / 21\end{array}$ \\
\hline & & & & & RT-PCR & $\mathrm{Q}(\mathrm{mtDNA})$ & 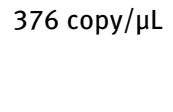 & $\begin{array}{r}50 / \\
30\end{array}$ & $\begin{array}{r}30 / \\
11 / \\
20 / 19\end{array}$ \\
\hline \multirow[t]{2}{*}{$\begin{array}{l}\text { Martínez-Galán } \\
\text { et al. (2008) }\end{array}$} & Spain & Serum & NA & Healthy & QMS-PCR & $M(14-3-3 \varrho)$ & 0.05 & $\begin{array}{r}106 / \\
74\end{array}$ & $\begin{array}{r}79 / \\
35 / \\
27 / 39\end{array}$ \\
\hline & & & & & QMS-PCR & M (ESR1) & 0.02 & $\begin{array}{r}106 / \\
74\end{array}$ & $\begin{array}{l}70 / \\
28 /\end{array}$ \\
\hline \multirow[t]{4}{*}{$\begin{array}{l}\text { Matuschek et al. } \\
\text { (2010) }\end{array}$} & Germany & Serum & Prospective & Healthy & MSP & $M(A P C)$ & NA & $\begin{array}{r}85 / \\
22\end{array}$ & $\begin{array}{l}25 / 2 / \\
60 / 20\end{array}$ \\
\hline & & & & & MSP & M (RASSF1A) & NA & $\begin{array}{r}85 / \\
22\end{array}$ & $\begin{array}{l}22 / 5 / \\
63 / 17\end{array}$ \\
\hline & & & & & MSP & M (GSTP1) & NA & $\begin{array}{r}76 / \\
16\end{array}$ & $\begin{array}{l}14 / 1 / \\
62 / 15\end{array}$ \\
\hline & & & & & MSP & $M(E S R 1)$ & NA & $\begin{array}{r}85 / \\
22\end{array}$ & $\begin{array}{l}32 / 5 / \\
53 / 17\end{array}$ \\
\hline \multirow[t]{4}{*}{ Mirza et al. (2007) } & India & Serum & NA & Healthy & MSP & $M(E r \alpha)$ & NA & $36 / 5$ & $\begin{array}{r}16 / 0 / \\
20 / 5\end{array}$ \\
\hline & & & & & MSP & M (PRB) & NA & $36 / 5$ & $\begin{array}{r}16 / 0 / \\
20 / 5\end{array}$ \\
\hline & & & & & MSP & M (BRCA1) & NA & $36 / 5$ & $\begin{array}{l}9 / 0 / \\
27 / 5\end{array}$ \\
\hline & & & & & MSP & M (TMS1) & NA & $36 / 5$ & $\begin{array}{l}4 / 0 / \\
32 / 5\end{array}$ \\
\hline
\end{tabular}


Table 1: (continued)

\begin{tabular}{|c|c|c|c|c|c|c|c|c|c|}
\hline $\begin{array}{l}\text { Study ID } \\
\text { Author, year }\end{array}$ & Country & Sample & Design & Controls & Method & Assay type & Cutoff & $\begin{array}{l}\text { No. } \\
\text { P/C }\end{array}$ & $\begin{array}{l}\text { TP/FP/ } \\
\text { FN/TN }\end{array}$ \\
\hline \multirow[t]{3}{*}{ Mirza et al. (2010) } & Canada & Serum & Prospective & Healthy & MSP & $M(\operatorname{Er} \alpha)$ & NA & $\begin{array}{r}55 / \\
30\end{array}$ & $\begin{array}{l}30 / 3 / \\
25 / 27\end{array}$ \\
\hline & & & & & MSP & M (PRB) & NA & $\begin{array}{r}53 / \\
53\end{array}$ & $\begin{array}{l}29 / 4 / \\
24 / 49\end{array}$ \\
\hline & & & & & MSP & $M(\mathrm{SFN})$ & NA & $\begin{array}{r}56 / \\
56\end{array}$ & $\begin{array}{l}33 / 7 / \\
23 / 49\end{array}$ \\
\hline \multirow[t]{4}{*}{ Müller et al. (2003) } & Austria & Serum & NA & Healthy & Fluorescent base PCR & M (ESR1) & NA & $\begin{array}{r}25 / \\
10\end{array}$ & $\begin{array}{r}7 / 0 / \\
18 / 10\end{array}$ \\
\hline & & & & & Fluorescent base PCR & M (APC) & NA & $\begin{array}{r}25 / \\
10\end{array}$ & $\begin{array}{r}6 / 0 / \\
19 / 10\end{array}$ \\
\hline & & & & & Fluorescent base PCR & $M(\mathrm{HIC}-1)$ & NA & $\begin{array}{r}25 / \\
10\end{array}$ & $\begin{array}{r}10 / 1 / \\
15 / 9\end{array}$ \\
\hline & & & & & Fluorescent base PCR & M (RASSF1A) & NA & $\begin{array}{r}25 / \\
10\end{array}$ & $\begin{array}{l}6 / 1 / \\
19 / 9\end{array}$ \\
\hline Ng et al. (2011) & China & Plasma & Retrospective & Healthy & MSRED-qPCR & M (SLC19A3) & 0.41 & $\begin{array}{r}39 / \\
20\end{array}$ & $\begin{array}{r}34 / 3 / \\
5 / 17\end{array}$ \\
\hline Nunes et al. (2018) & Portugal & Plasma & Retrospective & Mixed & MSP & $\begin{array}{l}M \\
\text { (SCGB3A1) }\end{array}$ & NA & $\begin{array}{r}108 / \\
103\end{array}$ & $\begin{array}{l}18 / \\
21 /\end{array}$ \\
\hline Oshiro et al. (2015) & Japan & Serum & Retrospective & Healthy & $\mathrm{dPCR}$ & Mut (PI3CA) & NA & $\begin{array}{r}110 / \\
30\end{array}$ & $\begin{array}{l}90 / 82 \\
25 / 0 / \\
85 / 30\end{array}$ \\
\hline \multirow[t]{5}{*}{$\begin{array}{l}\text { Panagopoulou et al. } \\
\text { (2019) }\end{array}$} & Greece & Plasma & Retrospective & Healthy & qMSP & M (SOX17) & NA & $\begin{array}{r}34 / \\
35\end{array}$ & $\begin{array}{l}23 / 2 / \\
11 / 33\end{array}$ \\
\hline & & & & & qMSP & $M($ WNT5A) & NA & $\begin{array}{r}34 / \\
35\end{array}$ & $\begin{array}{l}14 / 3 / \\
20 / 32\end{array}$ \\
\hline & & & & & qMSP & M (KLK10) & NA & $\begin{array}{r}34 / \\
35\end{array}$ & $\begin{array}{l}19 / 2 / \\
15 / 33\end{array}$ \\
\hline & & & & & qMSP & $\mathrm{M}(\mathrm{MSH} 2)$ & NA & $\begin{array}{r}34 / \\
35\end{array}$ & $\begin{array}{l}16 / 1 / \\
18 / 34\end{array}$ \\
\hline & & & & & qMSP & M (GATA3) & NA & $\begin{array}{r}35 / \\
35\end{array}$ & $\begin{array}{r}3 / 1 / \\
32 / 34\end{array}$ \\
\hline \multirow[t]{3}{*}{$\begin{array}{l}\text { Papadopoulou et al. } \\
\text { (2006) }\end{array}$} & Greece & Plasma & NA & Healthy & QPCR & Q & $10.8 \mathrm{ng} / \mathrm{mL}$ & $\begin{array}{r}68 / \\
54\end{array}$ & $\begin{array}{l}33 / 3 / \\
35 / 51\end{array}$ \\
\hline & & & & & MSP & M (RASSF1A) & NA & $\begin{array}{r}50 / \\
14\end{array}$ & $\begin{array}{l}13 / 0 / \\
37 / 14\end{array}$ \\
\hline & & & & & MSP & M (ATM) & NA & $50 / 9$ & $\begin{array}{l}7 / 0 / \\
43 / 9\end{array}$ \\
\hline \multirow[t]{3}{*}{ Rykova et al. (2004) } & Russia & Plasma & NA & NBC & MSP & M (RASSF1A) & NA & $17 / 6$ & $8 / 0 / 9 /$ \\
\hline & Russia & Plasma & NA & NBC & MSP & $M(\operatorname{RAR} \beta 2)$ & NA & $15 / 6$ & $\begin{array}{l}5 / 0 / \\
10 / 6\end{array}$ \\
\hline & Russia & Plasma & NA & NBC & MSP & $M(A P C)$ & NA & $10 / 6$ & $4 / 0 / 6 /$ \\
\hline $\begin{array}{l}\text { Schwarzenbach } \\
\text { et al. (2011) }\end{array}$ & Germany & Serum & NA & Healthy & $\begin{array}{l}\text { PCR-based fluorescence } \\
\text { microsatellite analyses }\end{array}$ & $\mathrm{LOH}$ & NA & $\begin{array}{r}102 / \\
53\end{array}$ & $\begin{array}{l}19 / 0 / \\
83 / 53\end{array}$ \\
\hline \multirow[t]{4}{*}{ Shan et al. (2016) } & China & Serum & Retrospective & Mixed & MSP & M (hMLH1) & NA & $\begin{array}{r}268 / \\
481\end{array}$ & $\begin{array}{r}75 / \\
87 / \\
193 / \\
394\end{array}$ \\
\hline & & & & & MSP & M (RASSF1A) & NA & $\begin{array}{r}268 / \\
481\end{array}$ & $\begin{array}{l}46 / \\
44 /\end{array}$ \\
\hline & & & & & & & & & $\begin{array}{r}222 / \\
437\end{array}$ \\
\hline & & & & & MSP & M (p16) & NA & $\begin{array}{r}268 / \\
481\end{array}$ & $\begin{array}{l}60 / \\
78 /\end{array}$ \\
\hline
\end{tabular}


Table 1: (continued)

\begin{tabular}{|c|c|c|c|c|c|c|c|c|c|}
\hline $\begin{array}{l}\text { Study ID } \\
\text { Author, year }\end{array}$ & Country & Sample & Design & Controls & Method & Assay type & Cutoff & $\begin{array}{l}\text { No. } \\
\text { P/C }\end{array}$ & $\begin{array}{l}\text { TP/FP/ } \\
\text { FN/TN }\end{array}$ \\
\hline & & & & & & & & & $\begin{array}{r}208 / \\
403\end{array}$ \\
\hline & & & & & MSP & M & NA & $268 /$ & $149 /$ \\
\hline & & & & & & (PCDHGB7) & & 481 & $223 /$ \\
\hline & & & & & & & & & $\begin{array}{r}119 / \\
258\end{array}$ \\
\hline & & & & & MSP & $M(S F N)$ & NA & $268 /$ & 197/ \\
\hline & & & & & & & & 481 & 287/ \\
\hline & & & & & & & & & $\begin{array}{l}71 / \\
194\end{array}$ \\
\hline & & & & & MSP & M (HOXD13) & NA & $268 /$ & $37 / 7 /$ \\
\hline & & & & & & & & 481 & $231 /$ \\
\hline \multirow{7}{*}{$\begin{array}{l}\text { Sharma et al. } \\
(2007)\end{array}$} & India & Serum & NA & Healthy & MSP & M (Cyclin D2) & NA & $36 / 4$ & $9 / 0 /$ \\
\hline & & & & & & & & & $27 / 4$ \\
\hline & India & Serum & & & MSP & $M(p 16)$ & NA & $36 / 4$ & $13 / 0 /$ \\
\hline & & & & & & & & & $23 / 4$ \\
\hline & India & Serum & & & MSP & $M(p 14)$ & NA & $36 / 4$ & $13 / 0 /$ \\
\hline & & & & & & & & & $23 / 4$ \\
\hline & India & Serum & & & MSP & M (Slit2) & NA & $36 / 4$ & $21 / 0 /$ \\
\hline \multirow{6}{*}{$\begin{array}{l}\text { Sharma et al. } \\
(2010)\end{array}$} & India & Serum & NA & Healthy & MSP & $M(B R C A 1)$ & NA & $100 /$ & $22 / 1 /$ \\
\hline & & & & & & & & 30 & $78 / 29$ \\
\hline & & & & & MSP & M (MGMT) & NA & $100 /$ & $26 / 1 /$ \\
\hline & & & & & & & & 30 & $74 / 29$ \\
\hline & & & & & MSP & M (GSTP1) & NA & $100 /$ & $22 / 1 /$ \\
\hline & & & & & & & & 30 & $78 / 29$ \\
\hline \multirow[t]{4}{*}{ Shaw et al. (2000) } & UK & Plasma & Prospective & NBC & QPCR & $\mathrm{LOH}$ & NA & $71 / 9$ & $22 / 0 /$ \\
\hline & & & & & & & & & $49 / 9$ \\
\hline & UK & Plasma & Prospective & NBC & QPCR & MI & NA & $71 / 9$ & $8 / 0 /$ \\
\hline & & & & & & & & & $63 / 9$ \\
\hline Shukla et al. (2006) & India & Serum & NA & Healthy & MSP & M (RASSF1A) & NA & $20 /$ & $15 / 0 /$ \\
\hline & & & & & & & & 20 & $5 / 20$ \\
\hline \multirow{6}{*}{$\begin{array}{l}\text { Skvortsova et al. } \\
(2006)\end{array}$} & Russia & Plasma & NA & Mixed & MSP & $M(\mathrm{HIC}-1)$ & NA & $20 /$ & $11 / 6 /$ \\
\hline & & & & & & & & 25 & $9 / 19$ \\
\hline & & & & & MSP & M (RASSF1A) & NA & $20 /$ & $3 / 1 /$ \\
\hline & & & & & & & & 25 & $17 / 24$ \\
\hline & & & & & MSP & $M(\operatorname{RAR} \beta 2)$ & NA & $20 /$ & $3 / 2 /$ \\
\hline & & & & & & & & 25 & $17 / 23$ \\
\hline \multirow[t]{4}{*}{ Stötzer et al. (2014) } & Germany & Plasma & NA & Healthy & Q-PCR & DI (ALU 115) & NA & $112 /$ & $71 / 0 /$ \\
\hline & & & & & & & & 28 & $41 / 28$ \\
\hline & & & & & $Q-P C R$ & DI (ALU 247) & NA & $112 /$ & $74 / 0 /$ \\
\hline & & & & & & & & 28 & $38 / 28$ \\
\hline \multirow[t]{8}{*}{ Taback et al. (2006) } & USA & Serum & Prospective & Healthy & MSP & $M($ RASSF1A) & NA & $33 /$ & $5 / 0 /$ \\
\hline & & & & & & & & 10 & $28 / 10$ \\
\hline & & & & & MSP & M (MGMT) & NA & $33 /$ & $2 / 0 /$ \\
\hline & & & & & & & & 10 & $31 / 10$ \\
\hline & & & & & MSP & $M($ RAR $\beta 2)$ & NA & $33 /$ & $1 / 0 /$ \\
\hline & & & & & & & & 10 & $32 / 10$ \\
\hline & & & & & MSP & $M(A P C)$ & NA & $33 /$ & $1 / 0 /$ \\
\hline & & & & & & & & 10 & $32 / 10$ \\
\hline \multirow[t]{3}{*}{ Tang et al. (2018) } & China & Serum & Retrospective & Healthy & Q-PCR & Q (ALU 115) & $300.96 \mathrm{ng} / \mathrm{mL}$ & $40 /$ & $26 /$ \\
\hline & & & & & & & & 40 & $12 /$ \\
\hline & & & & & & & & & $14 / 28$ \\
\hline
\end{tabular}


Table 1: (continued)

\begin{tabular}{|c|c|c|c|c|c|c|c|c|c|}
\hline $\begin{array}{l}\text { Study ID } \\
\text { Author, year }\end{array}$ & Country & Sample & Design & Controls & Method & Assay type & Cutoff & $\begin{array}{l}\text { No. } \\
\text { P/C }\end{array}$ & $\begin{array}{l}\text { TP/FP/ } \\
\text { FN/TN }\end{array}$ \\
\hline & & & & & Q-PCR & $\begin{array}{l}\text { DI (ALU 247/ } \\
\text { ALU 115) }\end{array}$ & $0.78 \mathrm{ng} / \mathrm{m}$ & $\begin{array}{r}40 / \\
40\end{array}$ & $\begin{array}{r}37 / 5 / \\
3 / 35\end{array}$ \\
\hline $\begin{array}{l}\text { Tangvarasittichai } \\
\text { et al. (2015) }\end{array}$ & Thailand & Plasma & NA & Healthy & QPCR & Q & $120 \mathrm{ng} / \mathrm{mL}$ & $\begin{array}{r}100 / \\
100\end{array}$ & $\begin{array}{r}100 / \\
13 / 0 /\end{array}$ \\
\hline $\begin{array}{l}\text { Umetani et al. } \\
(2006)\end{array}$ & USA & Serum & Retrospective & Healthy & Q-PCR & $\begin{array}{l}\text { DI (ALU 247/ } \\
\text { ALU 115) }\end{array}$ & 0.17 & $\begin{array}{r}83 / \\
51\end{array}$ & $\begin{array}{l}57 / \\
10 /\end{array}$ \\
\hline Wang et al. (2017) & China & Plasma & NA & NBC & QPCR & $\mathrm{DI}$ & 0.74 & $\begin{array}{r}51 / \\
28\end{array}$ & $\begin{array}{r}26 / 41 \\
37 / \\
14 /\end{array}$ \\
\hline $\begin{array}{l}\text { Wu and Tanaka } \\
\text { (2015) }\end{array}$ & USA & Plasma & NA & Healthy & QPCR & $\begin{array}{l}\mathrm{Q} \text { (telomeric } \\
\text { DNA) }\end{array}$ & 91.4 & $\begin{array}{r}47 / \\
42\end{array}$ & $\begin{array}{r}14 / 14 \\
43 / \\
10 / 4 /\end{array}$ \\
\hline \multirow[t]{3}{*}{$\begin{array}{l}\text { Yamamoto et al. } \\
\text { (2012) }\end{array}$} & Japan & Serum & Retrospective & Healthy & OS-MSP & M (GSTP1) & NA & $\begin{array}{r}154 / \\
87\end{array}$ & $\begin{array}{r}21 / 2 / \\
133 /\end{array}$ \\
\hline & & & & & OS-MSP & $M($ RASSF1A) & NA & $\begin{array}{r}154 / \\
87\end{array}$ & $\begin{array}{r}26 / 0 / \\
128 /\end{array}$ \\
\hline & & & & & OS-MSP & $M($ RAR-B) & NA & $\begin{array}{r}154 / \\
87\end{array}$ & $\begin{array}{r}26 / 4 / \\
128 /\end{array}$ \\
\hline Zhang et al. (2015) & China & Serum & Retrospective & Healthy & Q-PCR & $Q$ & 0.3 & $\begin{array}{r}100 / \\
104\end{array}$ & $\begin{array}{r}80 / \\
33 / \\
20 / 71\end{array}$ \\
\hline
\end{tabular}

M, methylation; Q, quantitative; LOH, loss of heterozygosity; Al, allelic imbalance; DI, DNA instability; Mut, mutation; PCR, polymerase chain reaction; MSP, methylation specific PCR; RFLP, restriction fragment length polymorphism; RT-PCR, reverse transcription polymerase chain reaction; ddPCR, droplet digital PCR; BS-Seq, bisulfite sequencing; OS-MSP, one step methylation specific PCR; RASSF1A, Ras association domain family member 1; GSTP1, glutathione S-transferase pi 1; CDKI2A, cyclin dependent kinase inhibitor 2A; BRCA1, BRCA1 DNA repair associated; RAR- $\beta 2$, retinoic acid receptor beta 2; APC, adenomatous polyposis coli; MGMT, o-6-methylguanine-DNA methyltransferase; Slit2, slit guidance ligand 2; HOXD13, homeobox D13; SFN, stratifin; PCDHGB7, protocadherin gamma subfamily B, 7; hMLH1, MutL homolog 1; ATM, ATM serine/threonine kinase; GATA3, GATA binding protein 3; MSH2, MutS homolog 2; KLK10, Kallikrein related peptidase 10; WNT5A, Wnt family member 5A; PI3CA, phosphatidylinositol-4,5-bisphosphate 3-kinase catalytic subunit alpha; SCGB3A1, secretoglobin family 3A member 1; SLC19A3, solute carrier family 19 member 3; HIC-1, HIC ZBTB transcriptional repressor 1; ER1, Estrogen receptor 1; ER $\alpha$, Estrogen receptor alpha; NBPF1, NBPF member 1; PPMA1, protein phosphatase, $\mathrm{Mg}^{2+} / \mathrm{Mn}^{2+}$ Dependent 1A; EGFR1, Epidermal Growth Factor Receptor; TWIST1, twist family BHLH transcription factor 1; PCDH10, protocadherin 10; DAPK1, death associated protein kinase 1; TP, true positive; FP, false positive; TN, true negative; FN, false negative; SE, sensitivity; SP, specificity; NA, not available.

(Figure 3B), 6.7 (95\% CI: 4.4-10.3, $\left.I^{2}: 80.85 \%\right)$ (Figure 3C), 0.23 (95\% CI: 0.16-0.34, $I^{2}$ : 92.49\%) (Figure 3D), 29 (95\% CI: 14-57, $I^{2}: 99 \%$ ) (Figure 4), and 0.91 (Figure 5A), respectively.

Furthermore, for qualitative approaches, the pooled SE and SP of cfDNA in the detection BC were obtained as 0.36 (95\% CI: 0.31-0.41, $I^{2}:$ 93.26\%) (Supplementary Material 1; Figure 1) and 0.98 (95\% CI: 0.96-0.99, $I^{2}$ : 95.82\%) (Supplementary Material 1; Figure 2), respectively. Besides, PLR was calculated as 14.9 (95\% CI: 9.2-4.2, $I^{2}$ : 88.43\%) (Supplementary Material 1; Figure 3) and NLR was estimated to be 0.66 (95\% CI: $0.61-0.71, I^{2}: 90.35 \%$ ) (Supplementary Material 1; Figure 4). The combined DOR was 23 (95\% CI: $14-$
37; $I^{2}: 99 \%$ ) (Supplementary Material 1; Figure 5), and the AUC for sROC was obtained as 0.79 (Figure 5B).

\section{Subgroups}

At this stage, we evaluated the diagnostic performance estimations in different subgroups based on the ethnicity of participants (Asian, Caucasian, and African), BC type (primary and metastatic), tumor stage (size) (T1-T2 vs. T3T4), histological Grade (G1-G2 vs. G3), lymph node status (positive compared to negative), qualitative assays 


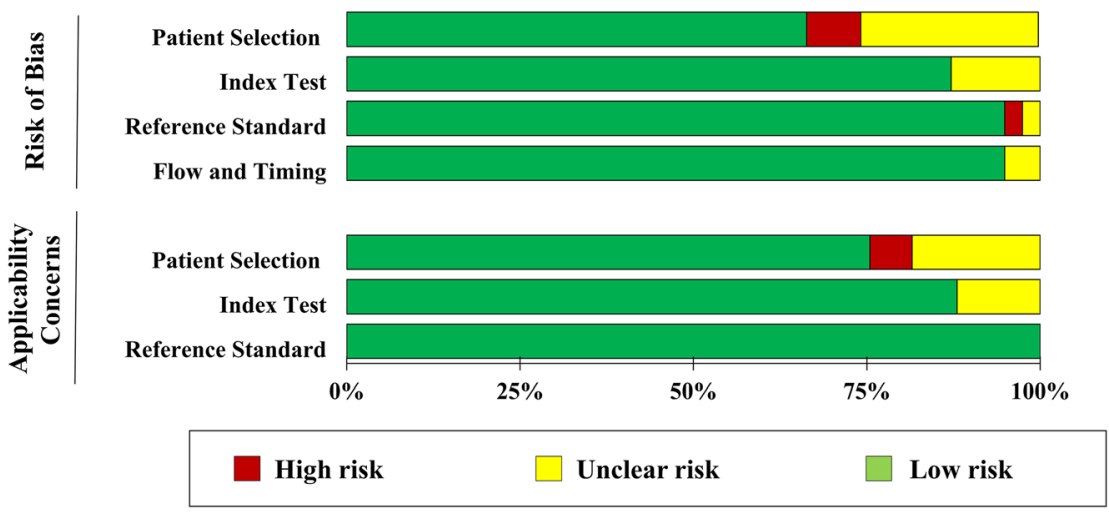

Figure 2: Quality assessment of included studies based on the Quality Assessment of Diagnostic Accuracy Studies (QUADAS-2) criterion.

Each bar represents the percent of studies considered as high risk, low risk, or unclear for both risk of bias and applicability concerns. (methylation compared to mutation), methylation genes (RASSF1A, RAR-ß2, p16, GSTP1, BRCA1, and APC), study design (prospective compared to retrospective), sample type (plasma compared to serum), publication year (before 2010 compared to after 2010), and sample size ( $\geq 100$ cases compared to $<100$ cases) (Table 2 and Supplementary Material 1; Table 1).

For qualitative assays, regarding the histological grade, the results show that cfDNA has a better diagnostic performance in patients with G3 than in patients with G1G2 (DOR: 32, AUC: 0.73 vs. DOR: 7, AUC: 0.69, respectively). In those assays performed using plasma, DOR was obtained as 18 and AUC was 0.77 , while the same estimations for those assays that were performed using serum, were obtained to be 25 and 0.80 , respectively. The articles published before 2010 showed superior performance in diagnosing $\mathrm{BC}$ compared to the articles published after 2010 (DOR: 64, AUC: 0.80 vs. DOR: 17, AUC: 0.78, respectively). Additionally, the assays with a sample size $<100$ cases (DOR: 25, AUC: 0.92) indicated slightly better performance when compared to the assays with a sample size $\geq 100$ cases (DOR: 15 , AUC: 0.73 ). Amongst the methylated genes, APC, p16, and BRCA1 showed the highest DOR (as 236, 124, and 100, respectively). However, the amounts of AUC for these genes were relatively low (as $0.40,0.38$, and 0.47 , respectively (Table 2).

For quantitative assays, the assays performed using plasma indicated better diagnostic performance compared to those assays that were performed using serum (DOR: 34, AUC: 0.92 vs. DOR: 24, AUC: 0.90, respectively). Regarding the factor of publication year, the articles published after 2010 showed better performance when compared to the articles published before 2010 (DOR: 32, AUC: 0.91 vs. DOR: 22, AUC: 0.90, respectively). Moreover, in this metaanalysis, the assays with a sample size $<100$ showed superior performance compared to the assays with a sample size $\geq 100$ cases (DOR: 37 , AUC: 0.92 vs. DOR: 22, AUC: 0.90 , respectively) (Supplementary Material 1; Table 1).

\section{Meta-regression}

In this phase of the study, we implemented metaregression to assess the source of heterogeneity based on the subgroup's results. For qualitative assays, the association between several covariates, including ethnicity, sample type, study design, sample size, histological type, and assay indicator in 6 different models, and the diagnostic performance was evaluated (Table 3). Based on the available reported data, we used the following covariates to perform meta-regression for quantitative assays: ethnicity, sample type, article design, sample size, and assay indicator in 5 different models (Supplementary Material 1; Table 2). Finally, meta-regression results demonstrated that none of the aforementioned covariates is a significant source of heterogeneity neither in quantitative nor in qualitative assays.

Besides, analyzing the threshold effect using the Spearman's correction coefficient implies that the threshold possibly is not a source of heterogeneity (coefficient: 0.099 and $\mathrm{p}=0.6$ for quantitative assays and coefficient; -0.143 and $\mathrm{p}=0.056$ for qualitative assays).

\section{Sensitivity analysis by single study omission}

Regardless of extensive subgroup analysis and metaregression, the source of heterogeneity was not found. Therefore, to further investigate the source heterogeneity, a sensitivity analysis has been performed by single-study omission for SE and SP in both quantitative and qualitative assays (Supplementary Material 1; Figure 6).

Based on the sensitivity analysis, the following articles were found as potential sources of heterogeneity: SE in quantitative assays: Tangvarasittichai 2013 [80], Agostini 2012 [32], and Tang 2018 [79]; SP of quantitative assays: Agostini 2012 [32] and Stötzer 2014 [77]; SE of 
A

\section{SENSITIVITY}

$0.72[0.55-0.86]$

$0.95[0.83-0.99]$

$0.73[0.59-0.85]$

$0.43[0.36-0.51]$

$0.50[0.41-0.59]$

$0.71[0.61-0.80]$

$0.79[0.73-0.84]$

$0.89[0.84-0.93]$

$0.98[0.87-1.00]$

$0.93[0.84-0.98]$

$0.70[0.53-0.83]$

$0.68[0.51-0.81]$

$0.54[0.39-0.68]$

$0.81[0.67-0.90]$

$0.38[0.21-0.56]$

$0.60[0.45-0.74]$

$0.76[0.62-0.87]$

$0.49[0.36-0.61]$

$0.66[0.57-0.75]$

$0.63[0.54-0.72]$

$0.93[0.80-0.98]$

$0.65[0.48-0.79]$

$1.00[0.96-1.00]$

$0.69[0.58-0.78]$

$0.73[0.58-0.84]$

$0.80[0.71-0.87]$

$0.80[0.71-0.86]$

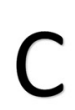

DLR POSITIVE

$2.89[1.21-6.91]$

$98.75[6.26-1000.00]$

$93.75[5.94-1000.00$
$3.27[1.89-5.66]$

$4.96[2.40-10.27]$

$5.00[2.53-9.88]$

$8.50[2.24-32.24]$

$3.40[1.97-5.87]$

$17.80[9.71-32.63]$

$26.36[3.85-180.48]$

$2.80[1.72-4.56]$

$8.56[2.94-24.91]$

$15.29[1.01-231.14$

$4.19[2.17-8.10]$

$2.57[1.77-3.72]$

$5.16[1.81-14.65]$

$1.64[0.97-2.76]$

$8.74[2.83-26.95]$

$38.24[2.44-598.76$

$36.70[2.34-574.87]$

7.40 [3.24 - 16.88]

$2.17[1.28-3.66]$

$7.44[4.53-12.23]$

$3.50[1.97-6.22]$

$3.84[2.22-6.65$

$2.52[1.87-3.40]$

$6.69[4.36-10.25]$
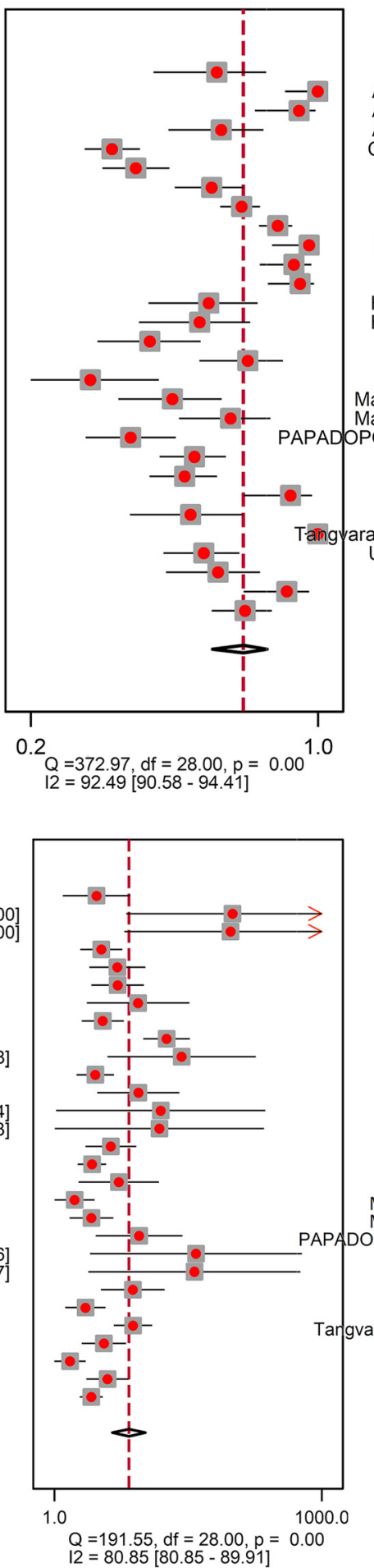

B

\section{Studyld}

Agassi/2015 Agostini/2012 Agostini/2012 Agostini/2012 Catarino/2008 Divella/2009 $\mathrm{Gal} / 2004$ Geng/2013 Gong/2012 Hashad/2012 Huang/2006 Huang/2006 Hussein/2019

Hussein/2019 Kohler/2009 Kohler/2009 Mahmoud/2016 Mahmoud/2016 MPULOU/2006 Stötzer/2014 Stötzer/2014 Tang/2018 rasittichai/2013 Umetani/2006 Wang/2017 Wu/2015 Zhang/2015

COMBINED

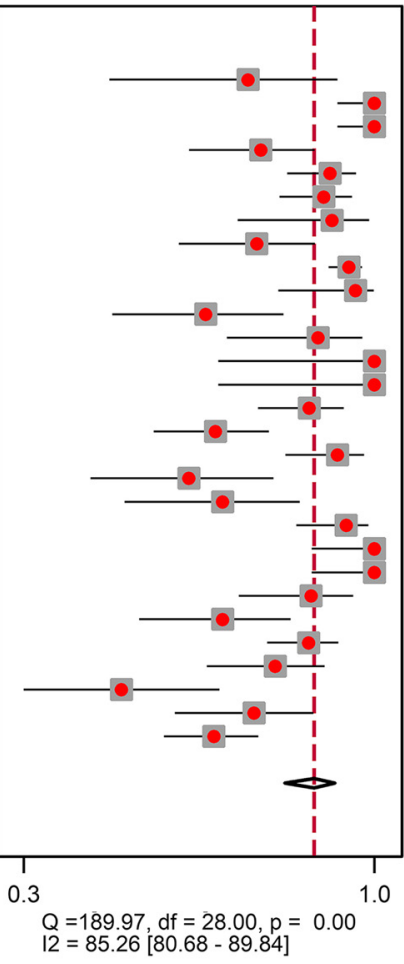
SPECIFICITY $0.75[0.48-0.93]$ $.00[0.93-1.00]$ $1.00[0.93-1.00$ $0.78[0.63-0.88$ $0.91[0.83-0.96$ $0.900 .81-0.96$ $0.92[0.73-0.99$ $0.77[0.61-0.88$ $0.95[0.91-0.98$ $0.96[0.81-1.00$ $0.67[0.48-0.82$ $0.89[0.71-0.98$ $1.00[0.69-1.00]$ $1.00[0.69-1.00]$ $0.87[0.77-0.94$ $0.69[0.56-0.79$ $0.63[0.44-0.80$ $0.70[0.51-0.85$ $0.94[0.85-0.99$ $1.00[0.88-1.00$ $1.00[0.88-1.00$ $0.88[0.73-0.96$ $0.70[0.53-0.83$ $0.87[0.79-0.93$ $0.80[0.67-0.90]$ $0.50031-0.69$ $0.76[0.61-0.88$

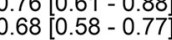
$0.88[0.82-0.92]$

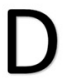

$12=85.26[80.68-89.84]$

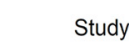

Agassi/2015 Agostini/2012 Agostini/2012 Agostini/2012 Catarino/2008 Divella/2009 $\mathrm{Gal} / 2004$ Hashad/2012 Huang/2006 Huang/2006 Hussein/2019 Hussein/2019 Kohler/2009 Kohler/2009 Leon/1977 Mahmoud/2016 Mahmoud/2016 POULOU/2006 Stötzer/2014 Stötzer/2014 Tang/2018 Tang/2018

Umetani/2006

Wang/2017

Wu/2015

COMBINED

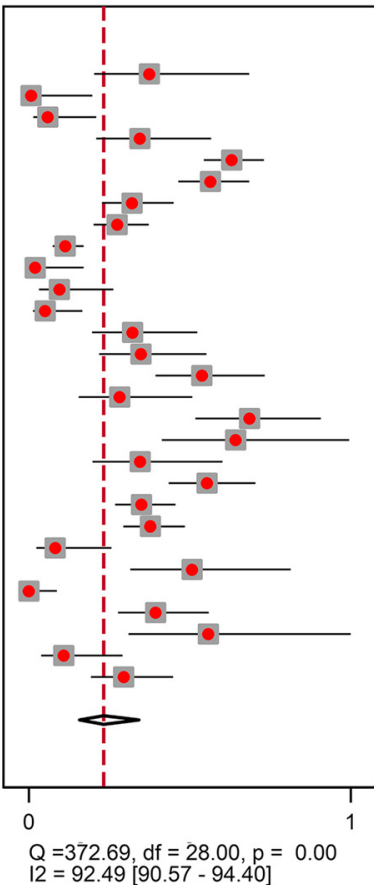

DLR NEGATIVE

$0.37[0.20-0.67]$ $0.01[0.01-0.20$ $0.06[0.02-0.21$ $0.34[0.21-0.56]$ $0.62[0.54-0.72$ $0.56[0.46-0.67$ $0.32[0.23-0.44$ $0.27[0.20-0.37]$ $0.12[0.08-0.17]$ $0.02[0.01-0.17$ $0.10[0.04-0.26$ $0.06[0.02-0.17$ $0.32[0.20-0.52$ 0.34 [0.22 - 0.54 ] $0.53[0.39-0.72$ $0.28[0.16-0.50$ $0.67[0.51-0.89$ $0.63[0.41-0.98$ $0.34[0.20-0.59$ $0.54[0.43-0.69$ $0.35[0.27-0.45$ $0.37[0.29-0.48$ $0.09[0.03-0.26$ $0.50[0.31-0.80$ $0.01[0.01-0.09$ $0.39[0.28-0.55$ $0.55[0.31-0.98$ $0.11[0.04-0.29$ $0.23[0.16-0.34]$

Figure 3: Forest plots for diagnostic performance estimates of quantitative circulating cell-free DNA assays.

(A) Sensitivity (B) Specificity (C) Positive likelihood ratio (D) Negative likelihood ratio. 


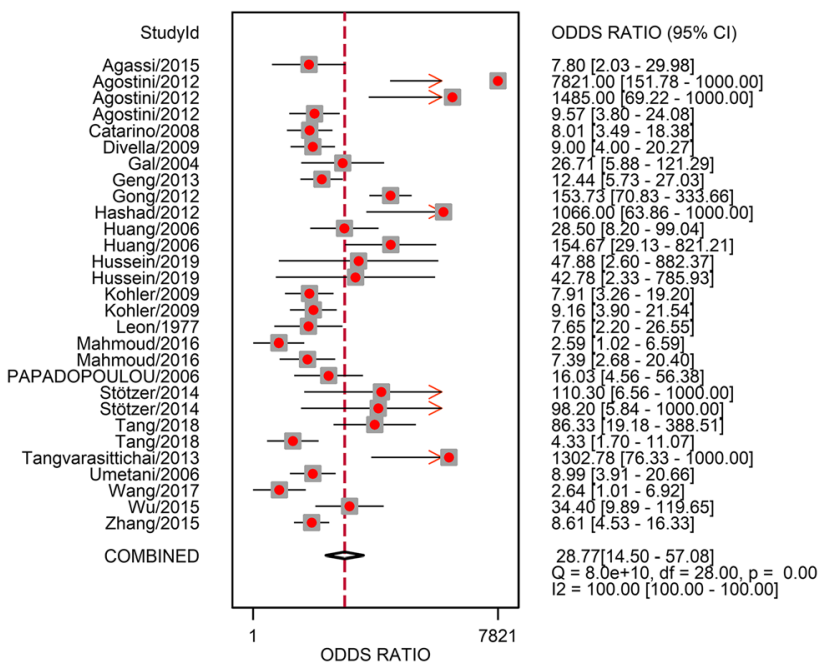

Figure 4: Forest plot for the pooled diagnostic odds ratio of quantitative circulating cell-free DNA in discriminating patients with breast cancer from controls. qualitative assays: Hoque 2006 [48], Kim 2010 [54], and Taback 2006 [78]; and SP of qualitative assays: Ebeid 2016 [42], Jing 2008 [51], and Jing 2010 [52]. Thereafter, all the main effect measures have been re-calculated after excluding the above-mentioned articles. Eliminating these studies has consequently led to a considerable decrease in heterogeneity in all measures of the main analysis, including SE, SP, PLR, NLR, and DOR (Table 4). Although no changes have been observed in their direction, a considerable drop has been observed in the amount of DOR in both qualitative (from 23 to 16.08) and quantitative assays (from 29 to 15.15). Therefore, to investigate how the above-mentioned articles affected the other analyses, all of them, including subgroups, clinical utility, meta-regression, and publication bias, have been re-performed after excluding those articles.

After deleting the articles at the previous stage, heterogeneity significantly dropped in almost all the
A

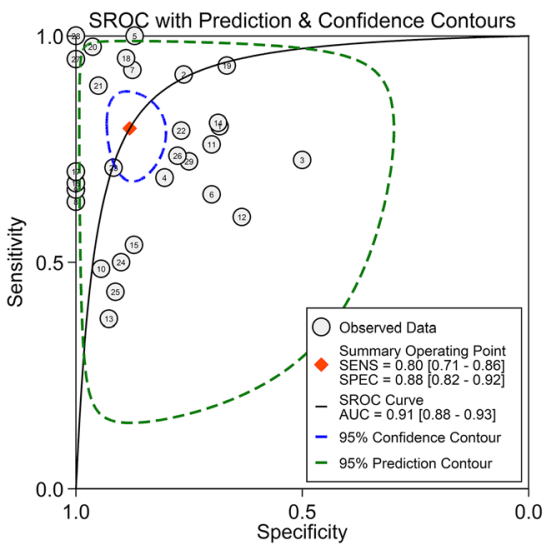

B

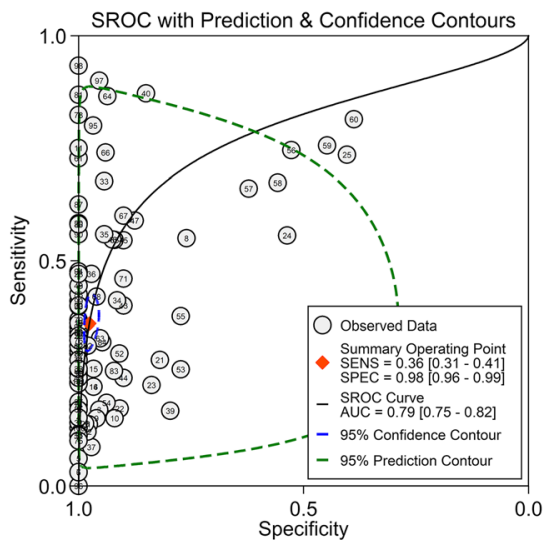

Figure 5: The summary receiver operating characteristic (SROC) curves for: (A) Diagnostic accuracy of quantitative circulating cell-free DNA assays in discriminating patients with breast cancer from controls. (B) Diagnostic accuracy of qualitative circulating cell-free DNA assays in discriminating patients with breast cancer from controls.

Table 2: Subgroups for qualitative assays.

\begin{tabular}{|c|c|c|c|c|c|c|c|c|c|c|c|}
\hline Subgroup & SE $(95 \% \mathrm{Cl})$ & $I^{2}, \%$ & SP $(95 \% \mathrm{Cl})$ & $I^{2}, \%$ & PLR (95\% Cl) & $I^{2}, \%$ & $\begin{array}{r}\text { NLR (95\% } \\
\mathrm{CI})\end{array}$ & $I^{2}, \%$ & $\begin{array}{r}\text { AUC (95\% } \\
\mathrm{CI})\end{array}$ & $\begin{array}{r}\text { DOR (95\% } \\
\mathrm{CI})\end{array}$ & $I^{2}, \%$ \\
\hline \multicolumn{12}{|l|}{ Ethnicity } \\
\hline Asian & $\begin{array}{r}0.39(0.32- \\
0.47)\end{array}$ & 95.6 & $\begin{array}{r}0.97(0.94- \\
0.99)\end{array}$ & 97.5 & $13.2(6.7-26.3)$ & 92.6 & $\begin{array}{r}0.53(0.47- \\
0.62)\end{array}$ & 93.5 & $\begin{array}{r}0.63(0.56- \\
0.71)\end{array}$ & $21(10-43)$ & 99 \\
\hline Caucasian & $\begin{array}{r}0.33(0.27- \\
0.41)\end{array}$ & 88.7 & $\begin{array}{r}0.97(0.95- \\
0.99)\end{array}$ & 84.4 & $12.8(6.6-24.8)$ & 63.7 & $\begin{array}{r}0.68(0.62- \\
0.78)\end{array}$ & 85.5 & $\begin{array}{r}0.80(0.78- \\
0.83)\end{array}$ & $19(9-37)$ & 99 \\
\hline African & $\begin{array}{r}0.34(0.23- \\
0.47)\end{array}$ & 88 & $\begin{array}{r}0.99(0.90- \\
1)\end{array}$ & 70 & $\begin{array}{r}49.8(2.7- \\
925.6)\end{array}$ & 35 & $\begin{array}{r}0.67(0.55- \\
0.81)\end{array}$ & 84.8 & $\begin{array}{r}0.71(0.61- \\
0.74)\end{array}$ & $\begin{array}{l}74(4- \\
1,533)\end{array}$ & 99 \\
\hline \multicolumn{12}{|l|}{ BC type } \\
\hline PBC & $\begin{array}{r}0.41(0.39- \\
0.42)\end{array}$ & 91.5 & $\begin{array}{r}0.93(0.92- \\
0.94)\end{array}$ & 85.8 & $7.51(5.1-10.8)$ & 82.5 & $\begin{array}{r}0.65(0.60- \\
0.70)\end{array}$ & 89.1 & $\begin{array}{r}0.82(0.71- \\
0.74)\end{array}$ & $13(9-18)$ & 50.3 \\
\hline MBC & $\begin{array}{r}0.53(0.37- \\
0.63)\end{array}$ & 88.6 & $\begin{array}{r}0.91(0.78- \\
0.97)\end{array}$ & 91.4 & $6(2.6-14)$ & 79.8 & $\begin{array}{r}0.52(0.38- \\
0.70)\end{array}$ & 95.1 & $\begin{array}{r}0.79(0.72- \\
0.82)\end{array}$ & $12(5-28)$ & 99 \\
\hline \multicolumn{12}{|c|}{ Tumor stage } \\
\hline $\mathrm{T} 1-\mathrm{T} 2$ & $\begin{array}{r}0.31(0.22- \\
0.42)\end{array}$ & 82.2 & $\begin{array}{r}0.93(0.88- \\
0.96)\end{array}$ & 48.2 & $4.5(2.6-7.8)$ & 2.78 & $\begin{array}{r}0.74(0.64- \\
0.85)\end{array}$ & 75.7 & $\begin{array}{r}0.82(0.71- \\
0.74)\end{array}$ & $6(3-12)$ & 99 \\
\hline
\end{tabular}


Table 2: (continued)

\begin{tabular}{|c|c|c|c|c|c|c|c|c|c|c|c|}
\hline Subgroup & SE $(95 \% \mathrm{Cl})$ & $I^{2}, \%$ & $\mathrm{SP}(95 \% \mathrm{Cl})$ & $I^{2}, \%$ & PLR $(95 \% \mathrm{Cl})$ & $I^{2}, \%$ & $\begin{array}{r}\text { NLR (95\% } \\
\mathrm{CI})\end{array}$ & $I^{2}, \%$ & $\begin{array}{r}\text { AUC (95\% } \\
\mathrm{Cl})\end{array}$ & $\begin{array}{r}\text { DOR (95\% } \\
\mathrm{Cl})\end{array}$ & $I^{2}, \%$ \\
\hline $3-\mathrm{T4}$ & $\begin{array}{r}0.40(0.33- \\
0.48)\end{array}$ & 49.7 & $\begin{array}{r}0.94(0.98- \\
0.97)\end{array}$ & 41 & $6.4(3.6-11.3)$ & 0 & $\begin{array}{r}0.65(0.60- \\
0.70)\end{array}$ & 15.1 & $\begin{array}{r}0.72(0.68- \\
0.75)\end{array}$ & $10(6-18)$ & 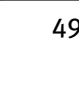 \\
\hline \multicolumn{12}{|l|}{ Histo. Grade } \\
\hline G1-G2 & $\begin{array}{r}0.30(0.27- \\
32)\end{array}$ & 93 & $\begin{array}{r}0.94(0.92- \\
0.97)\end{array}$ & 91 & $5(2.53-10.1)$ & 82.9 & $\begin{array}{r}0.73(0.65- \\
0.83)\end{array}$ & 94 & $\begin{array}{r}0.69(0.62- \\
0.72)\end{array}$ & $7(3-15)$ & 4 \\
\hline G3 & $\begin{array}{r}0.39(0.30- \\
0.48)\end{array}$ & 84.9 & $\begin{array}{r}0.98(0.94- \\
0.99)\end{array}$ & 95.4 & $19.8(6.4-61.2)$ & 74.1 & $\begin{array}{r}0.62(0.54- \\
0.73)\end{array}$ & 72 & $\begin{array}{r}0.73(0.69- \\
0.77)\end{array}$ & $\begin{array}{r}32(10- \\
102)\end{array}$ & \\
\hline \multicolumn{12}{|l|}{ Nodal status } \\
\hline Positive & $\begin{array}{r}0.43(0.33- \\
0.53)\end{array}$ & 88.4 & $\begin{array}{r}0.98(0.94- \\
0.99)\end{array}$ & 91.6 & $24.6(7.3-83.6)$ & 68.1 & $\begin{array}{r}0.58(0.49- \\
0.70)\end{array}$ & 78.6 & $\begin{array}{r}0.73(0.69- \\
0.77)\end{array}$ & $\begin{array}{r}42(12- \\
153)\end{array}$ & 9 \\
\hline Negative & $\begin{array}{r}0.35(0.26- \\
0.45)\end{array}$ & 86.7 & $\begin{array}{r}0.98(0.94- \\
1)\end{array}$ & 93 & $21(5.8-75.7)$ & 64.1 & $\begin{array}{r}0.66(0.57- \\
0.76)\end{array}$ & 77.9 & $\begin{array}{r}0.72(0.67- \\
0.76)\end{array}$ & $32(8-118)$ & \\
\hline cfDNA assay & & & & & & & & & & & \\
\hline $\begin{array}{l}\text { Methylation } \\
\text { (overall) }\end{array}$ & $\begin{array}{r}0.36(0.31- \\
0.41)\end{array}$ & 93.45 & $\begin{array}{r}0.97(0.95- \\
0.98)\end{array}$ & 95.9 & $12.6(7.8-20.1)$ & 87.8 & $\begin{array}{r}0.66(0.62- \\
0.71)\end{array}$ & 89.8 & $\begin{array}{r}0.76(0.72- \\
0.80)\end{array}$ & $19(12-31)$ & \\
\hline RASSF1A & $\begin{array}{r}0.34(0.24- \\
0.45)\end{array}$ & 91.17 & $\begin{array}{r}0.98(0.93- \\
0.99)\end{array}$ & 84.22 & $14.7(4.6-47.6)$ & 81.92 & $\begin{array}{r}0.68(0.57- \\
0.80)\end{array}$ & 92.53 & $\begin{array}{r}0.82(0.78- \\
0.85)\end{array}$ & $22(6-76)$ & \\
\hline RAR- $\beta 2$ & $\begin{array}{r}0.28(0.11- \\
0.54)\end{array}$ & 97 & $\begin{array}{r}0.95(0.91- \\
0.97)\end{array}$ & 0.0 & $5.3(2.2-13)$ & 5.71 & $\begin{array}{r}0.76(0.54- \\
1)\end{array}$ & 89.9 & $\begin{array}{r}0.82(0.78- \\
0.85)\end{array}$ & $7(2-23)$ & \\
\hline p16 & $\begin{array}{r}0.29(0.23- \\
0.35)\end{array}$ & 56.8 & $1(0.35-1)$ & 88.7 & $\begin{array}{r}124.1(0.2- \\
100767.7)\end{array}$ & 80.1 & $\begin{array}{r}0.71(0.65- \\
0.78)\end{array}$ & 85.2 & $\begin{array}{r}0.38(0.34- \\
0.42)\end{array}$ & $\begin{array}{c}124(0- \\
146861)\end{array}$ & 9 \\
\hline Subgroup & SE $(95 \% \mathrm{Cl})$ & $I^{2}, \%$ & SP $(95 \% \mathrm{Cl})$ & $I^{2}, \%$ & $\operatorname{PLR}(95 \% \mathrm{Cl})$ & $I^{2}, \%$ & $\begin{array}{r}\text { NLR (95\% } \\
\mathrm{CI})\end{array}$ & $I^{2}, \%$ & $\begin{array}{r}\operatorname{AUC}(95 \% \\
\mathrm{Cl})\end{array}$ & $\begin{array}{r}\text { DOR (95\% } \\
\mathrm{Cl})\end{array}$ & $I^{2}$, \\
\hline GSTP1 & $\begin{array}{r}0.19(0.14- \\
0.24)\end{array}$ & 37 & $\begin{array}{r}0.98(0.94- \\
0.99)\end{array}$ & 0 & $8.1(2.8-23.7)$ & 0 & $\begin{array}{r}0.83(0.78- \\
0.89)\end{array}$ & 36.2 & $\begin{array}{r}0.93(0.90- \\
0.95)\end{array}$ & $10(3-30)$ & 54. \\
\hline BRCA1 & $\begin{array}{r}0.29(0.24- \\
0.36)\end{array}$ & 18.8 & $1(0.85-1)$ & 0 & $\begin{array}{r}70.8(1.7- \\
2,995.2)\end{array}$ & 0 & $\begin{array}{r}0.71(0.65- \\
0.77)\end{array}$ & 31.5 & $\begin{array}{r}0.47(0.43- \\
0.52)\end{array}$ & $\begin{array}{r}100(2- \\
4,384)\end{array}$ & 9 \\
\hline APC & $\begin{array}{r}0.22(0.16- \\
0.30)\end{array}$ & 55 & $1(0.45-1)$ & 52.1 & $\begin{array}{r}184.1(0.2- \\
170381)\end{array}$ & 0.92 & $\begin{array}{r}0.78(0.71- \\
0.85)\end{array}$ & 57.1 & $\begin{array}{r}0.40(0.35- \\
0.44)\end{array}$ & $\begin{array}{l}236(0- \\
215209)\end{array}$ & 6.85 \\
\hline Mutation (PI3CA) & $\begin{array}{r}0.42(0.04- \\
0.93)\end{array}$ & 94.55 & $\begin{array}{r}0.99(0.85- \\
1)\end{array}$ & 64.2 & $\begin{array}{r}58.7(2.8- \\
1,237)\end{array}$ & 55.2 & $\begin{array}{r}0.59(0.18- \\
1.95)\end{array}$ & 97.9 & $\begin{array}{r}0.99(0.98- \\
1)\end{array}$ & $\begin{array}{r}100(3- \\
3,328)\end{array}$ & \\
\hline \multicolumn{12}{|l|}{ Study design } \\
\hline Retrospective & $\begin{array}{r}0.36(0.27- \\
0.46)\end{array}$ & 95.8 & $\begin{array}{r}0.96(0.93- \\
0.98)\end{array}$ & 98.11 & $10(5.3-18.7)$ & 94.5 & $\begin{array}{r}0.67(0.58- \\
0.76)\end{array}$ & 95.17 & $\begin{array}{r}0.78(0.74- \\
0.82)\end{array}$ & $15(18-29)$ & 9 \\
\hline Prospective & $\begin{array}{r}0.25(0.16- \\
0.28)\end{array}$ & 89.2 & $\begin{array}{r}0.94(0.89- \\
0.97)\end{array}$ & 32.3 & $4.4(2.2-8.6)$ & 0.0 & $\begin{array}{r}0.79(0.69- \\
0.91)\end{array}$ & 77.6 & $\begin{array}{r}0.86(0.83- \\
0.89)\end{array}$ & $6(3-12)$ & \\
\hline NA & $\begin{array}{r}0.40(0.34- \\
0.47)\end{array}$ & 90 & $\begin{array}{r}0.99(0.97- \\
1)\end{array}$ & 91.4 & $\begin{array}{r}43.1(14.1- \\
137.1)\end{array}$ & 78.4 & $\begin{array}{r}0.60(0.54- \\
0.67)\end{array}$ & 83.23 & $\begin{array}{r}0.78(0.74- \\
0.82)\end{array}$ & $\begin{array}{r}71(23- \\
218)\end{array}$ & \\
\hline \multicolumn{12}{|l|}{ Sample } \\
\hline Plasma & $\begin{array}{r}0.38(0.29- \\
0.48)\end{array}$ & 91.6 & $\begin{array}{r}0.97(0.92- \\
0.99)\end{array}$ & 92.3 & $11.6(5.2-25.8)$ & 78.5 & $\begin{array}{r}0.64(0.56- \\
0.75)\end{array}$ & 85.9 & $\begin{array}{r}0.77(0.74- \\
0.81)\end{array}$ & $18(8-41)$ & 9 \\
\hline Serum & $\begin{array}{r}0.35(0.30- \\
0.41)\end{array}$ & 93.8 & $\begin{array}{r}0.98(0.96- \\
0.99)\end{array}$ & 96.5 & $16.5(9.1-30)$ & 89.8 & $\begin{array}{r}0.66(0.61- \\
0.72)\end{array}$ & 91.4 & $\begin{array}{r}0.80(0.77- \\
0.84)\end{array}$ & $25(13-46)$ & 9 \\
\hline \multicolumn{12}{|l|}{ Pub. yea } \\
\hline$\geq 2010$ & $\begin{array}{r}0.39(0.32- \\
0.46)\end{array}$ & 94.8 & $\begin{array}{r}0.96(0.94- \\
0.98)\end{array}$ & 97.4 & $11(6.7-18.41)$ & 93.6 & $\begin{array}{r}0.63(0.57- \\
0.71)\end{array}$ & 94.4 & $\begin{array}{r}0.78(0.75- \\
0.82)\end{array}$ & $17(10-29)$ & 9 \\
\hline$<2010$ & $\begin{array}{r}0.32(0.26- \\
0.43)\end{array}$ & 89.6 & $\begin{array}{r}0.99(0.96- \\
1)\end{array}$ & 82.2 & $\begin{array}{r}43.4(9.3- \\
203.3)\end{array}$ & 29.7 & $\begin{array}{r}0.68(0.61- \\
0.75)\end{array}$ & 77.3 & $\begin{array}{r}0.80(0.76- \\
0.83)\end{array}$ & $\begin{array}{r}64(13- \\
303)\end{array}$ & 97. \\
\hline \multicolumn{12}{|l|}{ Sample size } \\
\hline$\geq 100$ & $\begin{array}{r}0.39(0.32- \\
0.46)\end{array}$ & 95.85 & $\begin{array}{r}0.96(0.92- \\
0.98)\end{array}$ & 97.5 & $9.4(5.2-7.16 .8$ & 92 & $\begin{array}{r}0.64(0.58- \\
0.71)\end{array}$ & 93.2 & $\begin{array}{r}0.73(0.69- \\
0.77)\end{array}$ & $15(8-27)$ & 9 \\
\hline$<100$ & $\begin{array}{r}0.34(0.27- \\
0.41)\end{array}$ & 85.6 & $\begin{array}{r}0.98(0.96- \\
0.99)\end{array}$ & 46.2 & $16.7(8.9-31.4)$ & 0 & $\begin{array}{r}0.68(0.61- \\
0.75)\end{array}$ & 83.3 & $\begin{array}{r}0.92(0.82- \\
0.94)\end{array}$ & $25(13-48)$ & 94 \\
\hline
\end{tabular}

SE, sensitivity; SP, specificity; PLR, positive likelihood ratio, NLR, negative Likelihood ratio; DOR, diagnostic odds ratio; PBC, primary breast cancer; MBC, metastatic breast cancer; RASSF1A, Ras association domain family member 1; GSTP1, glutathione S-transferase pi 1; p16, cyclin dependent kinase inhibitor 2A; BRCA1, BRCA1 DNA repair associated; RAR- $\beta 2$, retinoic acid receptor beta 2; APC, adenomatous polyposis coli; NA, not available. 
Table 3: Meta-regression for covariates in qualitative cell-free DNA assays (inverse variance weights).

\begin{tabular}{|c|c|c|c|c|c|}
\hline Var & Coeff. & Std. Err. & p-Value & RDOR & {$[95 \% \mathrm{Cl}]$} \\
\hline \multicolumn{6}{|l|}{ Model 1} \\
\hline Cte. & 2.225 & 0.6824 & 0.0016 & - & - \\
\hline $\mathrm{S}$ & -0.117 & 0.0712 & 0.1032 & - & - \\
\hline Ethnicity & -0.215 & 0.3474 & 0.5369 & 0.81 & $(0.40 ; 1.61)$ \\
\hline Sample type & -0.123 & 0.3556 & 0.7296 & 0.88 & $(0.44 ; 1.79)$ \\
\hline Indicator & 0.084 & 0.2264 & 0.7113 & 1.09 & $(0.69 ; 1.71)$ \\
\hline Study design & 0.096 & 0.1643 & 0.5618 & 1.10 & $(0.79 ; 1.53)$ \\
\hline Histo. type & -0.213 & 0.4229 & 0.6161 & 0.81 & $(0.35 ; 1.87)$ \\
\hline Sample size & -0.385 & 0.3387 & 0.2588 & 0.68 & $(0.35 ; 1.33)$ \\
\hline \multicolumn{6}{|l|}{ Model 2} \\
\hline Cte. & 1.726 & 0.5170 & 0.0012 & - & - \\
\hline $\mathrm{S}$ & -0.137 & 0.0698 & 0.0520 & - & - \\
\hline Ethnicity & -0.108 & 0.3376 & 0.7494 & 0.90 & $(0.46 ; 1.75)$ \\
\hline Sample type & 0.021 & 0.3361 & 0.9497 & 1.02 & $(0.52 ; 1.99)$ \\
\hline Indicator & 0.099 & 0.2277 & 0.6648 & 1.10 & $(0.70 ; 1.74)$ \\
\hline Study design & 0.117 & 0.1652 & 0.4801 & 1.12 & $(0.81 ; 1.56)$ \\
\hline Histo. type & -0.274 & 0.4258 & 0.5221 & 0.76 & $(0.33 ; 1.77)$ \\
\hline \multicolumn{6}{|l|}{ Model 3} \\
\hline Cte. & 1.806 & 0.5072 & 0.0006 & - & - \\
\hline $\mathrm{S}$ & -0.132 & 0.0696 & 0.0613 & - & - \\
\hline Ethnicity & -0.054 & 0.3295 & 0.8697 & 0.95 & $(0.49 ; 1.82)$ \\
\hline Sample type & -0.016 & 0.3330 & 0.9613 & 0.98 & $(0.51 ; 1.91)$ \\
\hline Indicator & 0.098 & 0.2281 & 0.6687 & 1.10 & $(0.70 ; 1.73)$ \\
\hline Histo. type & -0.341 & 0.4163 & 0.4148 & 0.71 & $(0.31 ; 1.63)$ \\
\hline \multicolumn{6}{|l|}{ Model 4} \\
\hline Cte. & 1.743 & 0.3601 & 0.0000 & - & - \\
\hline $\mathrm{S}$ & -0.131 & 0.0688 & 0.0598 & - & - \\
\hline Sample type & -0.025 & 0.3265 & 0.9403 & 0.98 & $(0.51 ; 1.87)$ \\
\hline Indicator & 0.090 & 0.2209 & 0.6855 & 1.09 & $(0.71 ; 1.70)$ \\
\hline Histo. type & -0.368 & 0.3824 & 0.3383 & 0.69 & $(0.32 ; 1.48)$ \\
\hline \multicolumn{6}{|l|}{ Model 5} \\
\hline Cte. & 1.734 & 0.3506 & 0.0000 & - & - \\
\hline $\mathrm{S}$ & -0.132 & 0.0683 & 0.0567 & - & - \\
\hline Indicator & 0.089 & 0.2196 & 0.6860 & 1.09 & $(0.71 ; 1.69)$ \\
\hline Histo. type & -0.377 & 0.3645 & 0.3040 & 0.69 & $(0.33 ; 1.41)$ \\
\hline \multicolumn{6}{|l|}{ Model 6} \\
\hline Cte. & 1.829 & 0.2562 & 0.0000 & - & - \\
\hline $\mathrm{S}$ & -0.133 & 0.0681 & 0.0537 & - & - \\
\hline Histo. type & -0.389 & 0.3622 & 0.2861 & 0.68 & $(0.33 ; 1.39)$ \\
\hline
\end{tabular}

Var, covariate; coeff., coefficient; Std. Err., standard error; RDOR, relative diagnostic odds ratio; Cte., constante; S, threshold effect in the model.

subgroups; however, according to Cochrane guidelines, the $I^{2}$ for some subgroups might still represent substantial heterogeneity $\left(I^{2}: 50-90 \%\right)$ [87]. It should be noted that, the effect measures have changed in almost all the subgroups (Supplementary Material 2; Tables 1 and 2), but the drawn conclusions remained unchanged. As well, meta-regression analysis did not recognize any of the covariate models as a potential source of heterogeneity (Supplementary Material 2; Tables 3 and 4). In the Fagan's nomograms, the intervals have slightly decreased between positive and negative post-test probabilities (Supplementary Material 2; Figures 1 and 2). Moreover, the result of Deek's funnel plot asymmetry test were similar for both of them (Supplementary Material 2; Figures 1 and 2). Of note, the overall results obtained from likelihood ratio scattergrams were similar (Supplementary Material 2; Figure 3). Therefore, regardless of the considerable decrease in the heterogeneity, the main conclusions from all the analyses remained unchanged. Correspondingly, this implies that, the effect of the deleted studies on the final results was minimal, so the results can be considered as stable. 
Table 4: The main effect measures after deleting studies.

Main effect measures for qualitative assays

\begin{tabular}{lrrrrrrr}
\hline & Value & 95\% Confidence interval & $\boldsymbol{I}^{2}, \%$ & & Value & 95\% Confidence interval & $\boldsymbol{I}^{\mathbf{2}}, \%$ \\
\hline SE & 0.37 & $0.32-0.43$ & 73.37 & SE & 0.75 & $0.68-0.82$ \\
SP & 0.96 & $0.94-0.98$ & 75.87 & SP & 0.84 & 71.85 \\
PLR & 10.43 & $6.24-12.43$ & 66.74 & PLR & 4.81 & 64.08 \\
NLR & 0.65 & $0.59-0.71$ & 69.36 & NLR & 0.30 & $3.39-6.82$ \\
DOR & 16.08 & $10.39-23.54$ & 75.87 & DOR & 15.15 & 55.40 \\
AUC & 0.76 & $0.72-0.80$ & - & AUC & 0.87 & 61.05 \\
\hline
\end{tabular}

A

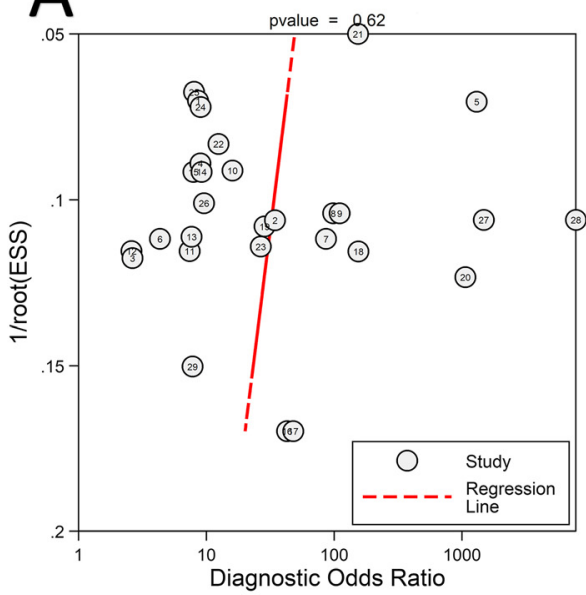

C

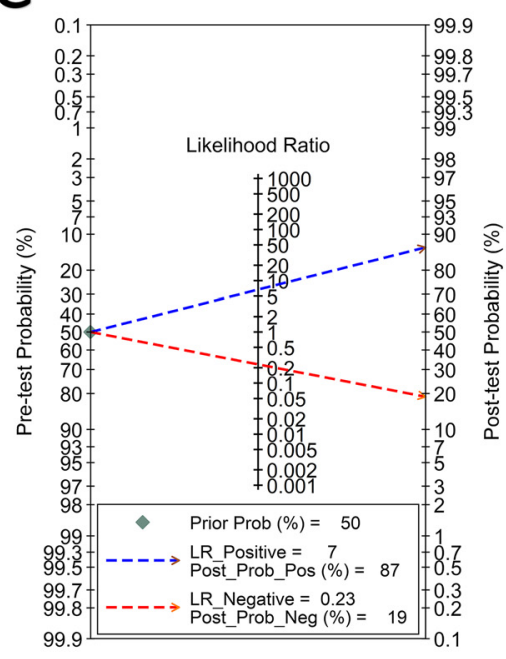

B

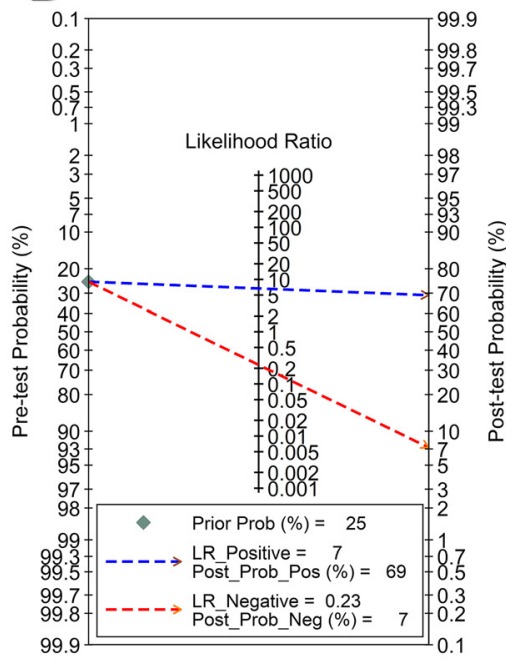

D

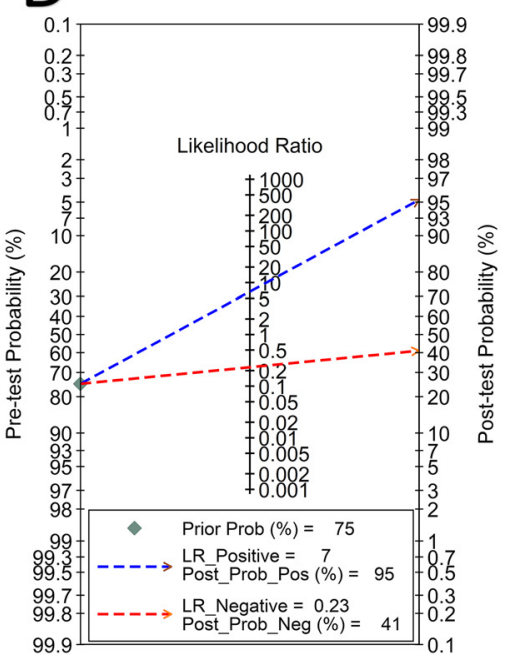

Figure 6: Publication bias analysis and clinical utility for quantitative assays. (A) Deeks' funnel plot asymmetry test for quantitative studies (B) Fagan monogram with $25 \%$ pretest probability (C) Fagan monogram with $50 \%$ pretest probability (D) Fagan monogram with $75 \%$ pretest probability.

\section{Clinical utility}

For quantitative cfDNA assays, the Fagan's nomogram demonstrated that when pretest probability was set at $25 \%$, cfDNA increased the post-test probability of a positive value up to $69 \%$, while there was $7 \%$ probability of cfDNA in $\mathrm{BC}$ patients with negative results (Figure 6B). With 50\% pretest probability, the correct detection succeeding a positive report increased to $87 \%$, while there was $19 \%$ chance of ignoring a patient with negative test result 
(Figure 6C). With 75\% pretest probability, the likelihood of a true diagnosis succeeding a positive test value was calculated as 95\%; however, the possibility of ignoring a patient with negative test result was 41\% (Figure 6D).

For qualitative cfDNA assays, with a pretest probability of $25 \%$, the probability of a true detection succeeding a positive test report was estimated to be $83 \%$; however, the chance of ignoring a $\mathrm{BC}$ case after a negative result was $18 \%$ (Figure $7 \mathrm{~B}$ ). With 50\% pretest probability, the correct detection leading to a positive result, increased up to $94 \%$, while there was $40 \%$ chance of ignoring a BC case with a negative result (Figure 7C). With 75\% pretest probability, the true diagnosis leading to a positive result, increased to $98 \%$; however, there was $66 \%$ chance of ignoring a patient with a negative test result (Figure 7D).
To evaluate the clinical values of different assays, we used a likelihood ratio scattergram [88]. Accordingly, this matrix is divided into the following four quadrants: the right upper quadrant (RUQ) (positive likelihood ratio (PLR) $>10$, negative likelihood ratio (NLR) $>0.1$ : confirmation only), the left upper quadrant (LUQ) (PLR $>10$, NLR $<0.1$ : exclusion and confirmation), the right lower quadrant (RLQ) (PLR <10, NLR >0.1: no exclusion or confirmation), and the left lower quadrant (LLQ) (PLR $<10$, NLR $<0.1$ : exclusion only) [88]. In the present study, the summary of both PLR and NLR for quantitative cf-DNA assays was plotted in the RUQ (Supplementary Material 1; Figure 6A). Moreover, for quantitative cfDNA assays, summary of both PLR and NLR was plotted in the RLQ (Supplementary Material 1; Figure 6B).
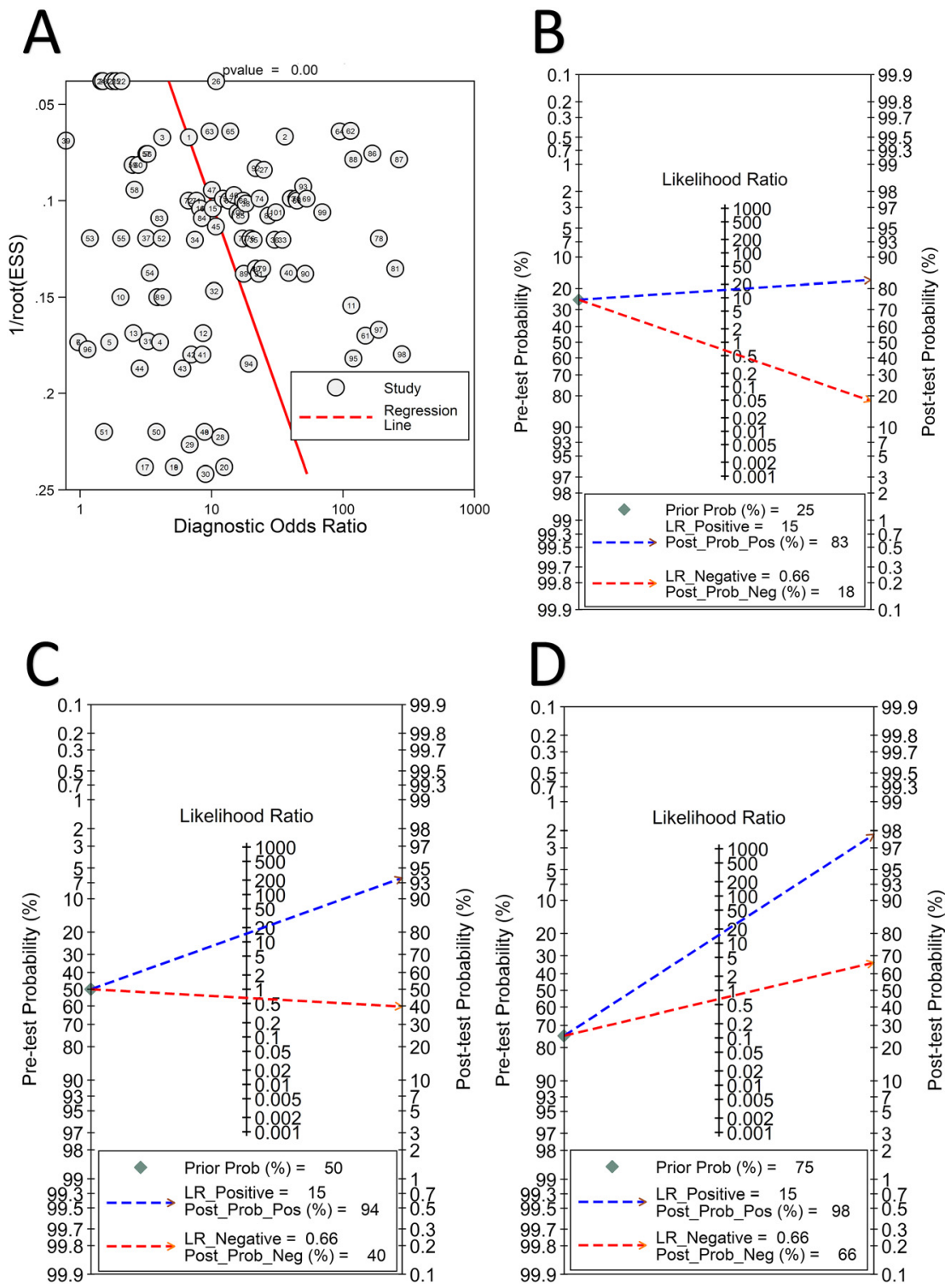

Figure 7: Publication bias analysis and clinical utility for qualitative assays. (A) Deeks' funnel plot asymmetry test for qualitative studies (B) Fagan monogram with $25 \%$ pretest probability (C) Fagan monogram with $50 \%$ pretest probability (D) Fagan monogram with $75 \%$ pretest probability. 


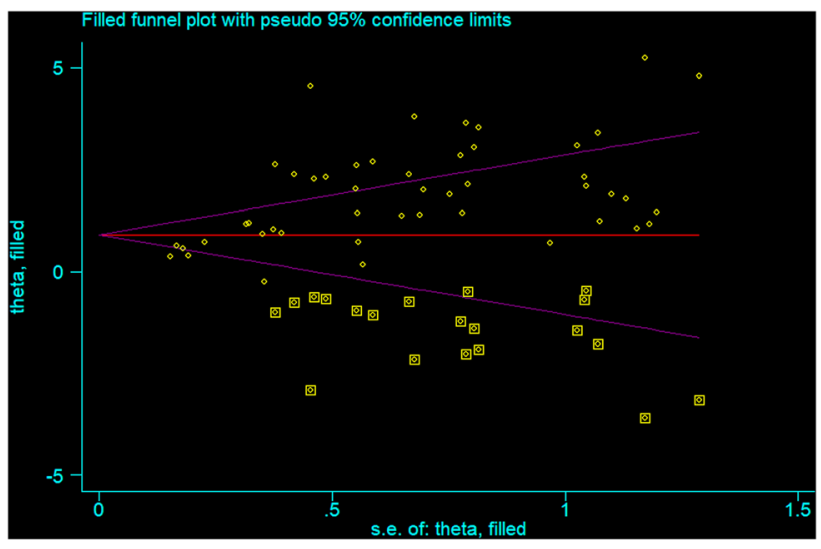

Figure 8: Trim and fill analysis for qualitative studies.

\section{Publication bias}

Deek's funnel plot asymmetry test have been employed to investigate publication bias. A coefficient of 11.89 (95\% CI: 5.33-18.45; $\mathrm{p}=0.001$ ) implied significant study bias among studies that used a qualitative methodological approach in order to assess cfDNA (Figure 7A). Accordingly, trim and fill analysis was performed to correct funnel plot asymmetry resulted from publication bias. The pooled point estimate was 1.78 (95\% CI: 1.46-2.11) prior to trimming the omitted studies. After conducting the test, the outcome changed to 0.904 (95\% CI: 0.56-1.23) (Figure 8). For those studies with a quantitative methodological approach to assess cfDNA, Deek's funnel plot test showed no publication bias with a coefficient of 2.84 (95\% CI: -0.61 to $6.29 ; \mathrm{p}=0.102$ ) (Figure 6A).

\section{Discussion}

Currently, BC screening through mammography was shown to reduce mortality up to $30 \%$ [3]. However, $13 \%$ of BC patients are missed by mammography results due to different factors [4, 5]. Additionally, false-positive detection in mammograms may cause over-treatment as well as radiation-induced disease [89]. Some common serumbased biomarkers such as cancer antigen CA15-3 and CEA, also did not show highly accurate result for the diagnosis of $\mathrm{BC}[9,89]$. Therefore, there is a need for finding novel noninvasive biomarkers to overcome the limitations resulted from conventional biomarkers and diagnostic approaches. The present updated meta-analysis aimed to address controversies in the previous published results regarding the diagnostic accuracy of cfDNA for BC.

In the present study, the pooled SE, SP, and sROC-AUC for quantitative approaches in 29 studies were obtained as $80 \%$,
$88 \%$, and 0.91 , respectively. In a meta-analysis conducted by Ling et al. [90] on 14 quantitative cfDNA studies for detecting $\mathrm{BC}$, the pooled SE, SP, and AUC were estimated as $78 \%, 83 \%$, and 0.93 . The higher rates of SE and SP in our study might be resulted from the advancement in the detection methods, which have been employed by the extra studies enrolled in the data synthesis. As well, these findings are comparable to the accuracy of conventional serum-based biomarkers for the detection of BC such as CEA, CA15-3, and human epidermal growth factor receptor 2 (HER2). Notably, in this study, CA15-13, as a common marker, showed a SE, SP, and AUC of $73 \%$, $85 \%$, and 0.78 , respectively [91]. Accordingly, in another study, the same estimations for HER2 have been evaluated to be $51 \%, 86 \%$, and 0.65 , respectively [92]. The valuation of CEA in the breast ductal secretions also revealed SE and AUC rates at $58 \%$ and 0.87 for detecting BC, respectively [93]. Lawicki et al. [94] in their study assessed the combined diagnostic accuracy of four markers, including macrophage colonystimulating factor (M-CSF), matrix metallopeptidase-9 (MMP-9), TIMP metallopeptidase Inhibitor-1 (TIMP-1), and CA 15-3, for the BC detection. This panel consisting of four biomarkers yielded SE, SP, and AUC rates as $84 \%, 83 \%$, and 0.91, respectively [94]. Therefore, quantitative cfDNA assays indicated a higher diagnostic performance when compared to the conventional serum-based biomarkers. However, few studies directly compared the accuracies of cfDNA and other serum based biomarkers.

For qualitative cfDNA assays, SE intensely reduced to $36 \%$, and AUC reduced to 0.79 , while SP enhanced up to $98 \%$. Among qualitative assays, the evaluation of the methylation status of single genes was the most common assay. By considering SE, SP, and AUC rates as 36\%, 97\%, and 0.78 , respectively, a slight difference was found between methylation assays and the pooled estimations for the overall qualitative assays. The main reason for the poor sensitivity rate of methylation analysis by cfDNA, regardless of high concordance with tumor tissue methylation status, can be considered to be the poor association of the selected genes with the pathogenesis of the BC. For example, in a meta-analysis done by $\mathrm{Li}$ et al. [95] on the accuracy of RASSF1A methylation using serum/plasma and tissue DNA for detecting $\mathrm{BC}$, the overall SE, SP, and AUC were obtained as $49 \%, 95 \%$, and 0.83 , respectively. There was a slight difference in terms of SE, SP, and AUC between the sample types (serum vs. tissue), indicating a low association of RASSF1A BC [95]. Additionally, in the present study, the pooled SE for hyper-methylated RASSF1A, RAR- $\beta 2$, p16, GSTP-1, BRCA1, and APC ranged from 19 to 34\%; however, there was a specificity between 95 and $100 \%$. The same results have been also observed for other qualitative approaches, including LOH, MI, and repeated element 
analysis. Regardless of low SE, it was shown that the excellent rate of SP for cfDNA methylation markers and other qualitative cfDNA assays can be used as auxiliary tools for enhancing the SP of the currently applied screening tools with lower SP in the risk assessment or the detection of BC.

DOR, as a single indicator of diagnostic performance, was also assessed in the current research. Generally, a DOR value of $>10$ is considered as good discriminatory performance $[96,97]$. In the present study, the pooled DOR for quantitative and qualitative cfDNA assays was obtained as 29 and 23, respectively. Moreover, for quantitative approaches, plasma-based assays yielded a better diagnostic performance compared to serum-based cfDNA assays (DOR: 34 vs. DOR: 24).

To the best of our knowledge, in comparison to the previous works performed with similar purposes [90, 98-102], the present study for the first time enrolled an adequate number of studies to compare the diagnostic performance of qualitative assays statistically between low grade and high grade BC patients. In this study, we evaluated the accuracy of qualitative cfDNA assays in different subgroups based on the tumor stage (size), histological grade, and lymph node's involvement. The results show that the qualitative assays can better differentiate patients at T3-T4 stages, with histological grade G3, and positive nodal involvement with higher accuracy (higher SE, SP, and DOR) compared to patients at T1-T2 stages, with histological grade G1-G2, and negative nodal involvement (Table 2). In other words, the qualitative cfDNA assays showed a better diagnostic performance in patients with advanced BC than patients with lower stages of BC. Based on this, these assays do not represent a remarkable clinical significance as a biomarker for early detection of BC [103]. These findings are of great importance as they suggest that the previous conclusion regarding the potential application of overall cfDNA assays as screening tools for early detection of BC should be interpreted with cautious [90]. However, it should be noted that the same analysis for quantitative assays was not possible due to lack of adequate data reported in the enrolled studies. Therefore, future studies by focusing on the evaluation of the diagnostic accuracy of quantitative cfDNA assays in $\mathrm{BC}$ patients at early and late stages are vital.

In the present study, another evaluated diagnostic estimation was likelihood ratio. PLR and NLR merge both SE and SP, so they are more clinically applicable than SE and SP. As a general criterion, PLR of $>10$ and NLR of $<0.1$ have been accepted as high accuracy performances [104]. Quantitative assays did not fulfill this criterion neither in overall nor in subgroup analysis. On the other side, qualitative assays showed an acceptable PLR (Overall: 14.94), but same as quantitative assays, they achieved no satisfying NLR. To provide a more clinically applicable view, likelihood scattergrams have been plotted using both PLR and NLR values [105]. The likelihood scattergram for quantitative assays clearly suggested that these assays are not robust enough neither for BC confirmation nor for exclusion. The likelihood scattergram for qualitative assays indicated that these assays have a satisfying performance only for confirming the diagnosis of $\mathrm{BC}$, but not for its exclusion.

There are some concerns on publication bias in qualitative assays. Results may be biased, since studies with greater sample size or positive results have higher chance of publishing. Nevertheless, after performing trim and fill analysis, no significant change has been observed. Besides, no publication bias was observed among quantitative assays based on the Deek's funnel plot asymmetry test. In this regard, meta-regression results suggested that none of the aforesaid covariates is a significant source of heterogeneity neither in quantitative nor in qualitative assays.

The major limitations of this study were as follows: regardless of comprehensive literature search, the number of quantitative cfDNA assays were small, so for more robust results, further studies must be done in the future. Additionally, we did not perform subgroup analysis regarding tumor stage, histological type, and nodal status in the included studies for quantitative assays, due to lack of enough data reported in the enrolled studies. Regardless of meta-regression in different models, in depth analysis of heterogeneity was not possible, since most of the included studies did not provide any proper information on age of participants, blinding methods, consecutive or successive sampling, and specimen preparation protocols. As well, lack of standardization of the detection techniques from sample acquisition to different cutoff values and interpretation of the results, may lead to hidden bias in the pooled estimations and a significant observed heterogeneity. Furthermore, a restriction for including English language literature may have introduced bias to the pooled analysis. Therefore, further larger prospective analyses with a focus on the standardized protocols either in technical aspects or in reporting criteria in the future are indispensable for producing the robust results and primary clinical considerations.

\section{Conclusions}

In the present study, we evaluated the diagnostic performance of both quantitative and qualitative cfDNA assays for discriminating patients with breast cancer from noncancerous/healthy controls. Correspondingly, the obtained key findings are summarized as follows: 
- The diagnostic performance of quantitative approaches in terms of SE, SP, sROC-AUC, and DOR were comparable to those of the conventional screening tools and serum-based biomarkers.

- The poor PLR and NLR values of quantitative assays suggested that these assays are not robust enough neither for BC confirmation nor for its exclusion.

- Qualitative cfDNA assays indicated poor sensitivity and also high value of NLR.

- The SP of qualitative assays were promising and these assays showed a satisfying performance only for confirming the diagnosis of $\mathrm{BC}$, but not for its exclusion.

- Qualitative assays showed superior accuracy in distinguishing patients at T3-T4 stages, with histological grade $\mathrm{G} 3$, and positive nodal involvement compared to patients at $\mathrm{T} 1-\mathrm{T} 2$ stages, with $\mathrm{G} 1-\mathrm{G} 2$, and negative nodal involvement when compared to normal controls. Accordingly, this does not have a remarkable clinical significance, as a biomarker for early detection, since most patients at the advanced stage of cancer can be well-diagnosed using the existing tools.

Performing consistent prospective studies in the future is needed to evaluate diagnostic performance of quantitative cfDNA assays in combination with conventional biomarkers. As well, incorporating qualitative cfDNA approaches along with a strong association with $\mathrm{BC}$ pathogenesis are mandatory to address the poor SE of qualitative assays.

Research funding: This research did not receive any specific grant from funding agencies in the public, commercial, or not-for-profit sectors.

Author contributions: All authors have accepted responsibility for the entire content of this manuscript and approved its submission.

Competing interests: Authors state no conflict of interest. Informed consent: Not applicable.

Ethical approval: Not applicable.

Data availability: The datasets generated during and/or analyzed during the current study are available from the corresponding author on reasonable request.

\section{References}

1. Bray F, Ferlay J, Soerjomataram I, Siegel RL, Torre LA, Jemal A. Global cancer statistics 2018: GLOBOCAN estimates of incidence and mortality worldwide for 36 cancers in 185 countries. Cancer J Clin 2018;68:394-424.
2. Böhm D, Keller K, Wehrwein N, Lebrecht A, Schmidt M, Kölbl H, et al. Serum proteome profiling of primary breast cancer indicates a specific biomarker profile. Oncol Rep 2011;26:1051-6.

3. Yu D, Tong Y, Guo X, Feng L, Jiang Z, Ying S, et al. Diagnostic value of concentration of circulating cell-free DNA in breast cancer: a meta-analysis. Front Oncol 2019;9:95.

4. Oeffinger KC, Fontham ET, Etzioni R, Herzig A, Michaelson JS, Shih YC, et al. Breast cancer screening for women at average risk: 2015 guideline update from the American Cancer Society. Jama 2015; 314:1599-614.

5. Lehman CD, Arao RF, Sprague BL, Lee JM, Buist DS, Kerlikowske K, et al. National performance benchmarks for modern screening digital mammography: update from the breast cancer surveillance consortium. Radiol 2017;283:49-58.

6. Olsen 0 , Gøtzsche PC. Screening for breast cancer with mammography. Cochrane Database Syst Rev 2001;4:Cd001877.

7. Khan SA, Reddy D, Gupta S. Global histone post-translational modifications and cancer: biomarkers for diagnosis, prognosis and treatment? World J Biol Chem 2015;6:333-45.

8. Lumachi F, Norberto L, Marino F, Basso SM, Marzano B, Chiara GB. Hormone receptor rate, MIB-1 score and serum tumour markers CEA and CA 15-3 relationship in elderly women with pT1-2 breast cancer. Anticancer Res 2010;30:4701-4.

9. Molina R, Auge JM, Farrus B, Zanón G, Pahisa J, Muñoz M, et al. Prospective evaluation of carcinoembryonic antigen (CEA) and carbohydrate antigen 15.3 (CA 15.3) in patients with primary locoregional breast cancer. Clin Chem 2010;56:1148-57.

10. Volckmar AL, Sültmann H, Riediger A, Fioretos T, Schirmacher P, Endris V, et al. A field guide for cancer diagnostics using cell-free DNA: from principles to practice and clinical applications. Genes Chromosom Cancer 2018;57:123-39.

11. Diaz LA, Jr., Bardelli A. Liquid biopsies: genotyping circulating tumor DNA. J Clin Oncol 2014;32:579-86.

12. Hao TB, Shi W, Shen XJ, Qi J, Wu XH, Wu Y, et al. Circulating cellfree DNA in serum as a biomarker for diagnosis and prognostic prediction of colorectal cancer. Br J Canc 2014;111:1482-9.

13. Zonta E, Nizard P, Taly V. Assessment of DNA integrity, applications for cancer research. Adv Clin Chem 2015;70:197-246.

14. Wang R, Li X, Zhang H, Wang K, He J. Cell-free circulating tumor DNA analysis for breast cancer and its clinical utilization as a biomarker. Oncotarget 2017;8:75742-55.

15. Salvi S, Gurioli G, De Giorgi U, Conteduca V, Tedaldi G, Calistri D, et al. Cell-free DNA as a diagnostic marker for cancer: current insights. Onco Targets Ther 2016;9:6549-59.

16. Bettegowda C, Sausen M, Leary RJ, Kinde I, Wang Y, Agrawal N, et al. Detection of circulating tumor DNA in early- and late-stage human malignancies. Sci Transl Med 2014;6:224ra24.

17. Dawson SJ, Rueda OM, Aparicio S, Caldas C. A new genomedriven integrated classification of breast cancer and its implications. EMBO J 2013;32:617-28.

18. Forshew T, Murtaza M, Parkinson C, Gale D, Tsui DW, Kaper F, et al. Noninvasive identification and monitoring of cancer mutations by targeted deep sequencing of plasma DNA. Sci Transl Med 2012;4:136ra68.

19. Garcia-Murillas I, Schiavon G, Weigelt B, Ng C, Hrebien S, Cutts RJ, et al. Mutation tracking in circulating tumor DNA predicts relapse in early breast cancer. Sci Transl Med 2015;7:302ra133.

20. Beaver JA, Jelovac D, Balukrishna S, Cochran R, Croessmann S, Zabransky DJ, et al. Detection of cancer DNA in plasma of patients with early-stage breast cancer. Clin Canc Res 2014;20:2643-50. 
21. Oshiro C, Kagara N, Naoi Y, Shimoda M, Shimomura A, Maruyama $\mathrm{N}$, et al. PIK3CA mutations in serum DNA are predictive of recurrence in primary breast cancer patients. Breast Canc Res Treat 2015;150:299-307.

22. Leary RJ, Sausen M, Kinde I, Papadopoulos N, Carpten JD, Craig D, et al. Detection of chromosomal alterations in the circulation of cancer patients with whole-genome sequencing. Sci Transl Med 2012;4:162ra154.

23. Liberati A, Altman DG, Tetzlaff J, Mulrow C, Gøtzsche PC, loannidis JPA, et al. The PRISMA statement for reporting systematic reviews and meta-analyses of studies that evaluate healthcare interventions: explanation and elaboration. BMJ 2009;339: b2700.

24. Whiting PF, Rutjes AW, Westwood ME, Mallett S, Deeks JJ, Reitsma JB, et al. QUADAS-2: a revised tool for the quality assessment of diagnostic accuracy studies. Ann Intern Med 2011;155:529-36.

25. Belias M, Rovers MM, Reitsma JB, Debray TPA, IntHout J. Statistical approaches to identify subgroups in meta-analysis of individual participant data: a simulation study. BMC Med Res Methodol 2019;19:183.

26. Akobeng AK. Understanding diagnostic tests 2: likelihood ratios, pre- and post-test probabilities and their use in clinical practice. Acta Paediatr 2007;96:487-91.

27. Deeks JJ, Macaskill P, Irwig L. The performance of tests of publication bias and other sample size effects in systematic reviews of diagnostic test accuracy was assessed. J Clin Epidemiol 2005;58:882-93.

28. Duval S, Tweedie R. Trim and fill: a simple funnel-plot-based method of testing and adjusting for publication bias in metaanalysis. Biometrics 2000;56:455-63.

29. Zhang M, He Y, Zhang X, Zhang M, Kong L. A pooled analysis of the diagnostic efficacy of plasmic methylated septin- 9 as a novel biomarker for colorectal cancer. Biomed Rep 2017;7:353-60.

30. Myers L, Sirois MJ. Spearman Rank correlation coefficient. The concise encyclopedia of statistics. New York, NY: Springer New York; 2008:502-5 pp.

31. Agassi R, Czeiger D, Shaked G, Avriel A, Sheynin J, Lavrenkov K, et al. Measurement of circulating cell-free DNA levels by a simple fluorescent test in patients with breast cancer. Am J Clin Pathol 2015;143:18-24.

32. Agostini M, Enzo M, Bedin C, Belardinelli V, Goldin E, Del Bianco $P$, et al. Circulating cell-free DNA: a promising marker of regional lymphonode metastasis in breast cancer patients. Canc Biomarkers 2012;11:89-98.

33. Beaver JA, Jelovac D, Balukrishna S, Cochran RL, Croessmann S, Zabransky DJ, et al. Detection of cancer DNA in plasma of patients with early-stage breast cancer. Clin Canc Res 2014;20:2643.

34. Beck J, Urnovitz HB, Mitchell WM, Schütz E. Next generation sequencing of serum circulating nucleic acids from patients with invasive ductal breast cancer reveals differences to healthy and nonmalignant controls. Mol Canc Res 2010;8:335-42.

35. Board RE, Wardley AM, Dixon JM, Armstrong AC, Howell S, Renshaw L, et al. Detection of PIK3CA mutations in circulating free DNA in patients with breast cancer. Breast Canc Res Treat 2010;120:461-7.

36. Catarino R, Ferreira MM, Rodrigues H, Coelho A, Nogal A, Sousa A, et al. Quantification of free circulating tumor DNA as a diagnostic marker for breast cancer. DNA Cell Biol 2008;27: 415-21.
37. Chen X, Bonnefoi H, Diebold-Berger S, Lyautey J, Lederrey C, Faltin-Traub E, et al. Detecting tumor-related alterations in plasma or serum DNA of patients diagnosed with breast cancer. Clin Canc Res 1999;5:2297.

38. Chimonidou M, Strati A, Malamos N, Georgoulias V, Lianidou ES. SOX17 promoter methylation in circulating tumor cells and matched cell-free DNA isolated from plasma of patients with breast cancer. Clin Chem 2013;59:270-9.

39. Chimonidou M, Tzitzira A, Strati A, Sotiropoulou G, Sfikas C, Malamos N, et al. CST6 promoter methylation in circulating cellfree DNA of breast cancer patients. Clin Biochem 2013;46: 235-40.

40. Divella R, Tommasi S, Lacalamita R, Daniele A, Abbate I, Garrisi VM, et al. Circulating hTERT DNA in early breast cancer. Anticancer Res 2009;29:2845-9.

41. Dulaimi E, Hillinck J, de Caceres II, Al-Saleem T, Cairns P. Tumor suppressor gene promoter hypermethylation in serum of breast cancer patients. Clin Canc Res 2004;10:6189-93.

42. Ebeid SA, Abd El Moneim NA, Hewala TI, Hemida MA, Shehata G, El-Taher N. Assessment of hypermethylation of RASSF1A and protocadherin-10 tumor suppressor genes in breast cancer females: a six-year disease-free survival case-control study. MEJC 2016;7:9-20.

43. Fu D, Ren C, Tan H, Wei J, Zhu Y, He C, et al. Sox17 promoter methylation in plasma DNA is associated with poor survival and can be used as a prognostic factor in breast cancer. Medicine 2015;94:e637.

44. Gal S, Fidler C, Lo Y, Taylor M, Han C, Moore J, et al. Quantitation of circulating DNA in the serum of breast cancer patients by realtime PCR. Br J Canc 2004;90:1211-5.

45. Geng Y, Gao Y, Ju H, Yan F. Diagnostic and prognostic value of plasma and tissue ubiquitin-like, containing PHD and RING finger domains 1 in breast cancer patients. Canc Sci 2013;104:194-9.

46. Gong B, Xue J, Yu J, Li H, Hu H, Yen H, et al. Cell-free DNA in blood is a potential diagnostic biomarker of breast cancer. Oncol Lett 2012;3:897-900.

47. Hashad D, Sorour A, Ghazal A, Talaat I. Free circulating tumor DNA as a diagnostic marker for breast cancer. J Clin Lab Anal 2012;26: 467-72.

48. Hoque MO, Feng Q, Toure P, Dem A, Critchlow CW, Hawes SE, et al. Detection of aberrant methylation of four genes in plasma DNA for the detection of breast cancer. J Clin Oncol 2006;24:4262-9.

49. Huang ZH, Li LH, Hua D. Quantitative analysis of plasma circulating DNA at diagnosis and during follow-up of breast cancer patients. Canc Lett 2006;243:64-70.

50. Hussein NA, Mohamed SN, Ahmed MA. Plasma ALU-247, ALU-115, and cfDNA integrity as diagnostic and prognostic biomarkers for breast cancer. Appl Biochem Biotechnol 2019;187:1028-45.

51. Jing $F$, Jun L, Yong Z, Wang Y, Fei X, Zhang J, et al. Multigene methylation in serum of sporadic Chinese female breast cancer patients as a prognostic biomarker. Oncology 2008;75:60-6.

52. Jing F, Yuping W, Yong C, Jie L, Jun L, Xuanbing T, et al. CpG island methylator phenotype of multigene in serum of sporadic breast carcinoma. Tumor Biol 2010;31:321-31.

53. Jing F, Zhang J, Tao J, Zhou Y, Jun L, Tang X, et al. Hypermethylation of tumor suppressor genes BRCA1, p16 and 14-3-3s in serum of sporadic breast cancer patients. Oncol Res Treat 2007;30:14-9.

54. Kim J-H, Shin M-H, Kweon S-S, Park MH, Yoon JH, Lee JS, et al. Evaluation of promoter hypermethylation detection in serum as a 
diagnostic tool for breast carcinoma in Korean women. Gynecol Oncol 2010;118:176-81.

55. Kirkizlar E, Zimmermann B, Constantin T, Swenerton R, Hoang B, Wayham N, et al. Detection of clonal and subclonal copy-number variants in cell-free DNA from patients with breast cancer using a massively multiplexed PCR methodology. Transl Oncol 2015;8: 407-16.

56. Leon S, Shapiro B, Sklaroff D, Yaros M. Free DNA in the serum of cancer patients and the effect of therapy. Canc Res 1977;37: 646-50.

57. Li D, Li P, Wu J, Yi J, Dou Y, Guo X, et al. Methylation of NBPF1 as a novel marker for the detection of plasma cell-free DNA of breast cancer patients. Clin Chim Acta 2018;484:81-6.

58. Li Z, Guo X, Tang L, Peng L, Chen M, Luo X, et al. Methylation analysis of plasma cell-free DNA for breast cancer early detection using bisulfite next-generation sequencing. Tumor Biol 2016;37: 13111-9.

59. Mahmoud EH, Fawzy A, Ahmad OK, Ali AM. Plasma circulating cell-free nuclear and mitochondrial DNA as potential biomarkers in the peripheral blood of breast cancer patients. Asian Pac J Canc Prev 2015;16:8299-305.

60. Martínez-Galán J, Torres B, Del Moral R, Muñoz-Gámez JA, MartínOliva D, Villalobos $M$, et al. Quantitative detection of methylated ESR1 and 14-3-3-sigma gene promoters in serum as candidate biomarkers for diagnosis of breast cancer and evaluation of treatment efficacy. Canc Biol Ther 2008;7:958-65.

61. Matuschek C, Bölke E, Lammering G, Gerber PA, Peiper M, Budach W, et al. Methylated APC and GSTP1 genes in serum DNA correlate with the presence of circulating blood tumor cells and are associated with a more aggressive and advanced breast cancer disease. Eur J Med Res 2010;15:277-86.

62. Mirza S, Sharma G, Parshad R, Srivastava A, Gupta SD, Ralhan R. Clinical significance of Stratifin, ERalpha and PR promoter methylation in tumor and serum DNA in Indian breast cancer patients. Clin Biochem 2010;43:380-6.

63. Mirza S, Sharma G, Prasad CP, Parshad R, Srivastava A, Gupta SD, et al. Promoter hypermethylation of TMS1, BRCA1, ERalpha and PRB in serum and tumor DNA of invasive ductal breast carcinoma patients. Life Sci 2007;81:280-7.

64. Müller HM, Widschwendter A, Fiegl H, Ivarsson L, Goebel G, Perkmann E, et al. DNA methylation in serum of breast cancer patients: an independent prognostic marker. Canc Res 2003;63: 7641-5.

65. Ng EK, Leung CP, Shin VY, Wong CL, Ma ES, Jin HC, et al. Quantitative analysis and diagnostic significance of methylated SLC19A3 DNA in the plasma of breast and gastric cancer patients. PLoS One 2011;6:e22233.

66. Nunes SP, Moreira-Barbosa C, Salta S, Palma de Sousa S, Pousa I, Oliveira J, et al. Cell-free DNA methylation of selected genes allows for early detection of the major cancers in women. Cancers (Basel) 2018;10:357.

67. Panagopoulou M, Karaglani M, Balgkouranidou I, Biziota E, Koukaki T, Karamitrousis E, et al. Circulating cell-free DNA in breast cancer: size profiling, levels, and methylation patterns lead to prognostic and predictive classifiers. Oncogene 2019;38: 3387-401.

68. Papadopoulou E, Davilas E, Sotiriou V, Georgakopoulos E, Georgakopoulou S, Koliopanos A, et al. Cell-free DNA and RNA in plasma as a new molecular marker for prostate and breast cancer. Ann N Y Acad Sci 2006;1075:235-43.
69. Rykova EY, Skvortsova TE, Laktionov PP, Tamkovich SN, Bryzgunova OE, Starikov AV, et al. Investigation of tumor-derived extracellular DNA in blood of cancer patients by methylationspecific PCR. Nucleos Nucleot Nucleic Acids 2004;23:855-9.

70. Schwarzenbach H, Müller V, Milde-Langosch K, Steinbach B, Pantel K. Evaluation of cell-free tumour DNA and RNA in patients with breast cancer and benign breast disease. Mol Biosyst 2011; 7:2848-54.

71. Shan M, Yin H, Li J, Li X, Wang D, Su Y, et al. Detection of aberrant methylation of a six-gene panel in serum DNA for diagnosis of breast cancer. Oncotarget 2016;7:18485-94.

72. Sharma G, Mirza S, Parshad R, Srivastava A, Gupta SD, Pandya P, et al. Clinical significance of promoter hypermethylation of DNA repair genes in tumor and serum DNA in invasive ductal breast carcinoma patients. Life Sci 2010;87:83-91.

73. Sharma G, Mirza S, Prasad CP, Srivastava A, Gupta SD, Ralhan R. Promoter hypermethylation of p16INK4A, p14ARF, CyclinD2 and Slit2 in serum and tumor DNA from breast cancer patients. Life Sci 2007;80:1873-81.

74. Shaw JA, Smith BM, Walsh T, Johnson S, Primrose L, Slade MJ, et al. Microsatellite alterations plasma DNA of primary breast cancer patients. Clin Canc Res 2000;6:1119-24.

75. Shukla S, Mirza S, Sharma G, Parshad R, Gupta SD, Ralhan R. Detection of RASSF1A and RARbeta hypermethylation in serum DNA from breast cancer patients. Epigenetics 2006;1:88-93.

76. Skvortsova TE, Rykova EY, Tamkovich SN, Bryzgunova OE, Starikov AV, Kuznetsova NP, et al. Cell-free and cell-bound circulating DNA in breast tumours: DNA quantification and analysis of tumour-related gene methylation. $\mathrm{Br} J$ Canc 2006;94: 1492-5.

77. Stötzer OJ, Lehner J, Fersching-Gierlich D, Nagel D, Holdenrieder S. Diagnostic relevance of plasma DNA and DNA integrity for breast cancer. Tumor Biol 2014;35:1183-91.

78. Taback B, Giuliano AE, Lai R, Hansen N, Singer FR, Pantel K, et al. Epigenetic analysis of body fluids and tumor tissues: application of a comprehensive molecular assessment for early-stage breast cancer patients. Ann N Y Acad Sci 2006;1075:211-21.

79. Tang Z, Li L, Shen L, Shen X, Ju S, Cong H. Diagnostic value of serum concentration and integrity of circulating cell-free DNA in breast cancer: a comparative study with CEA and CA15-3. Lab Med 2018;49:323-8.

80. Tangvarasittichai 0 , Jaiwang $\mathrm{W}$, Tangvarasittichai S. The plasma DNA concentration as a potential breast cancer screening marker. Indian J Clin Biochem 2015;30:55-8.

81. Umetani N, Giuliano AE, Hiramatsu SH, Amersi F, Nakagawa T, Martino S, et al. Prediction of breast tumor progression by integrity of free circulating DNA in serum. J Clin Oncol 2006;24: 4270-6.

82. Wang W, Liang M, Ma G, Li L, Zhou W, Xia T, et al. Plasma cell-free DNA integrity plus circulating tumor cells: a potential biomarker of no distant metastasis breast cancer. Neoplasma 2017;64: 611-8.

83. Wu X, Tanaka $\mathrm{H}$. Aberrant reduction of telomere repetitive sequences in plasma cell-free DNA for early breast cancer detection. Oncotarget 2015;6:29795-807.

84. Yamamoto N, Nakayama T, Kajita M, Miyake T, Iwamoto T, Kim SJ, et al. Detection of aberrant promoter methylation of GSTP1, RASSF1A, and RAR 32 in serum DNA of patients with breast cancer by a newly established one-step methylation-specific PCR assay. Breast Canc Res Treat 2012;132:165-73. 
85. Zachariah RR, Schmid S, Buerki N, Radpour R, Holzgreve W, Zhong $X$. Levels of circulating cell-free nuclear and mitochondrial DNA in benign and malignant ovarian tumors. Obstet Gynecol 2008;112:843-50.

86. Zhang L, Song X, Wang X, Xie Y, Wang Z, Xu Y, et al. Circulating DNA of HOTAIR in serum is a novel biomarker for breast cancer. Breast Canc Res Treat 2015;152:199-208.

87. Higgins JPT, Thomas J, Chandler J, Cumpston M, Li T, Page MJ, et al, editors. Cochrane handbook for systematic reviews of interventions, 2nd ed. Chichester (UK): John Wiley \& Sons; 2019.

88. Yang H, Wang $\mathrm{H}$, Zhang C, Tong Z. The accuracy of microRNA-210 in diagnosing lung cancer: a systematic review and metaanalysis. Oncotarget 2016;7:63283.

89. Kim SJ, Chung SY, Chang JM, Cho N, Han W, Moon WK. Ultrasound screening of contralateral breast after surgery for breast cancer. Eur J Radiol 2015;84:54-60.

90. Lin Z, Neiswender J, Fang B, Ma X, Zhang J, Hu X. Value of circulating cell-free DNA analysis as a diagnostic tool for breast cancer: a meta-analysis. Oncotarget 2017;8:26625.

91. Thriveni K, Deshmane V, Ramaswamy G, Krishnamoorthy L. Diagnostic significance of CA15-3 with combination of HER-2/neu values at 85 th percentiles in breast cancer. Indian J Clin Biochem 2013;28:136-40.

92. Leyland-Jones B, Smith BR. Serum HER2 testing in patients with HER2-positive breast cancer: the death knell tolls. Lancet Oncol 2011;12:286-95.

93. Tang S, Zhou F, Sun Y, Wei L, Zhu S, Yang R, et al. CEA in breast ductal secretions as a promising biomarker for the diagnosis of breast cancer: a systematic review and meta-analysis. Breast Canc 2016;23:813-9.

94. Ławicki S, Gtażewska EK, Sobolewska M, Będkowska GE, Szmitkowski M. Plasma levels and diagnostic utility of macrophage colony-stimulating factor, matrix metalloproteinase-9, and tissue inhibitor of metalloproteinases-1 as new biomarkers of breast cancer. Ann Lab Med 2016;36:223-9.

95. Li M, Wang C, Yu B, Zhang X, Shi F, Liu X. Diagnostic value of RASSF1A methylation for breast cancer: a meta-analysis. Biosci Rep 2019;39. https://doi.org/10.1042/bsr20190923.
96. Swets JA. Measuring the accuracy of diagnostic systems. Science 1988;240:1285-93.

97. Choupani J, Nariman-Saleh-Fam Z, Saadatian Z, Ouladsahebmadarek E, Masotti A, Bastami M. Association of mir-196a-2 rs11614913 and mir-149 rs2292832 polymorphisms with risk of cancer: an updated meta-analysis. Front Genet 2019; 10:186.

98. Cheuk IWY, Shin VY, Kwong A. Detection of methylated circulating DNA as noninvasive biomarkers for breast cancer diagnosis. J Breast Cancer 2017;20:12.

99. Yu D, Tong Y, Guo X, Feng L, Jiang Z, Ying S, et al. Diagnostic value of concentration of circulating cell-free DNA in breast cancer: a meta-analysis. Front Oncol 2019;9:95.

100. Zhou Y, Wang C, Zhu H, Lin Y, Pan B, Zhang X, et al. Diagnostic accuracy of PIK3CA mutation detection by circulating free DNA in breast cancer: a meta-analysis of diagnostic test accuracy. PLoS One 2016;11:e0158143.

101. Ye M, Huang T, Ying Y, Li J, Yang P, Ni C, et al. Detection of 14-3-3 sigma $(\sigma)$ promoter methylation as a noninvasive biomarker using blood samples for breast cancer diagnosis. Oncotarget 2017;8:9230.

102. Bastami M, Choupani J, Saadatian Z, Zununi Vahed S, Ouladsahebmadarek E, Mansoori Y, et al. Evidences from a systematic review and meta-analysis unveil the role of miRNA polymorphisms in the predisposition to female neoplasms. Int J Mol Sci 2019;20:5088.

103. Pepe MS, Etzioni R, Feng Z, Potter JD, Thompson ML, Thornquist $M$, et al. Phases of biomarker development for early detection of cancer. J Natl Cancer Inst 2001;93:1054-61.

104. McGee S. Simplifying likelihood ratios. J Gen Intern Med 2002; 17:646-9.

105. Stengel D, Bauwens K, Sehouli J, Ekkernkamp A, Porzsolt F. Original Paper: a likelihood ratio approach to meta-analysis of diagnostic studies. J Med Screen 2003;10:47-51.

Supplementary Material: The online version of this article offers supplementary material (https://doi.org/10.1515/cclm-2021-0193). 